\title{
Küçük Devlet Neden Süper Güç İttifakından Ayrılır? Soğuk Savaş Dönemi Irak, Misır ve İran Örnekleri*
}

\author{
Feyza Nur Atabay Öztürk**
}

\section{$\ddot{O} z$}

Bu makalenin amacı, süper güç ve küçük devlet arasındaki ittifakın sona ermesinin iç siyasal nedenlerini incelemektir. İttifak literatürü, ağırlıklı olarak klasik realizmin ve neo-realizmin etkisi altında olduğu için, devlet davranışlarını etkileyen temel faktörün uluslararası sistemin yapısı ve bu yapıdaki güç değişimi olduğu ileri sürülmüştür. Devlet düzeyindeki dinamikler değerlendirmeye dahil edilmemiştir. Soğuk Savaş boyunca sistemin yapısında bir değişim söz konusu değilken bile bazı devletlerin, mevcut ittifaklarını sonlandırarak yeni ittifak tercihlerine yönelmiş olmaları, bu yönelimin nedenlerini anlamak için devletin iç koşullarındaki değişimlere bakmanın gerekli olduğunu göstermektedir. Bu argümanı test etmek için, Irak, Misır ve İran'ın Soğuk Savaş dönemindeki ittifak ayrılışları ele alınmıştır. Bu ülkeler, siyasi tarihlerindeki pek çok darbe deneyimi, sahip oldukları istikrarsız siyasal atmosferleri ve ekonomik değişkenlikleri ile ilgili hipotezlerin test edilebilmesi için zengin bir örneklem sunmaktadır. Araştırma, rejim değişikliği, lider değişikliği, travmatik olay ve iktidarın meşruluk krizi gibi dinamiklerin devletin mevcut ittifak ilişkisini sonlandırmasının başlıca nedenleri olduğunu göstermektedir.

Anahtar Kelimeler: İttifak, İç Nedenler, Travma, Soğuk Savaş, Ortadoğu, Süper Güç

\footnotetext{
* $\quad$ Bu makale, aynı temaya sahip yazarın yüksek lisans çalışmasından faydalanılarak yazılmıştır.

** Doktora Öğrencisi, Kocaeli Üniversitesi, TR, Uluslararası İlişkiler, orcid.org//00000003-3999-88-78, feyzanuratabay@gmail.com
} 


\title{
Why Does the Small State Disengage from the Superpower Alliance? Cases of Iraq, Egypt and Iran during Cold War
}

\author{
Feyza Nur Atabay Öztürk ${ }^{* * *}$
}

\begin{abstract}
This article aims to examine the domestic political reasons of the end of the alliance between the superpower and the small state. Since the Alliance literature is predominantly influenced by classical realism and neo-realism, it is argued that the main factor affecting state behavior is the structure of the international system and the change in the distribution of power in this structure. State-level dynamics are excluded from the evaluation. Even though there was no change in the structure of the system during Cold War, some states had inclined to new alliance preferences by terminating their existing alliances, which indicates, that it is necessary to look at the changes in the state's internal conditions in order to understand the reasons for this new orientation. To test this argument, during Cold War, the alliance disengagement of Iraq, Egypt and Iran are discussed. These countries provide a rich case to test related hypotheses because of many coup experiences in their political history, their unstable political atmosphere and their economic variability. The research shows that dynamics such as regime change, change in leadership, traumatic event and the legitimacy crisis of power are the main reasons for the state to end the existing alliance relationship.
\end{abstract}

Keywords: Alliance, Domestic Reasons, Trauma, Cold War, Middle East, Superpower

*** PhD Student, Kocaeli University, TR, International Relations, orcid.org//0000-00033999-88-78, feyzanuratabay@gmail.com 


\section{Giriş}

İkinci Dünya Savaşı'ndan sonra gücü elinde tutan iki devlet, $A B D$ ve Sovyetler Birliği, kendi ideolojilerini paylaşan devletlerle ilişkilerini güçlendirerek, rakibi süper güç karşısında üstünlük kurma arayışında olmuştur. Süper güçlerin her ikisi de kendi bloğunda yer alan devletlerle kimi zaman resmi ve yazılı formlarda, kimi zaman gayri resmi şekilde, geniş kapsamlı ekonomik ve askeri işbirlikleriyle ittifak kurmuştur. Devletlerin davranışlarını etkileyen temel unsurun, uluslararası sistemin yapısı olduğunu ileri süren realist ve neo-realist bakış açısına göre, Soğuk Savaş süresince, sistemin iki kutuplu yapısı hakimiyetini sürdürmeye devam ettiği için, mevcut ittifak ilişkilerinin dönemin sonuna kadar sürmesi beklenmiştir. ${ }^{1}$ Fakat pratikte ortaya çıkan sonuç bu olmamıştır. Devletler, mevcut ittifaklarından ayrılarak yeni bir ilişki ağı kurmuşlardır. $\mathrm{Bu}$ çalışma, devletlerin ittifaka ilişkin kararlarını etkileyen unsurları, sistemsel etkilere odaklanan argümanlarla açıklamayı yetersiz bulduğu için devlet içi dinamiklerin etkisine vurgu yapmaktadır. İttifak ayrılışının sebepleri olarak devletin iç nedenlerini dikkate alan bir değerlendirme, daha geniş bir bakış açısı sağlaması sebebiyle devletlerin ittifak ilişkilerine dair söyleyecek daha çok söze sahiptir.

Hans Morgenthau, ittifakların, ortak çıkarlara sahip devletlerin, bir araya gelmesiyle oluştuğunu ifade eder. ${ }^{2}$ Devletlerin çıkarları, doğal olarak belirlenmiş, sabit ve değişmez unsurlar değildirler. ${ }^{3}$ Devletin sahip olduğu çıkarların neler olduğuna, iktidardaki erk ve elitler karar vermektedir. ${ }^{4} \mathrm{Bu}$ erkin sahip olduğu değer yargıları, hayat görüşü, devletin geleceğine dair tasavvurlarını da şekillendirmektedir. Çünkü farklı toplumsal tabanların, farklı gelecek beklentileri ve öncelikleri vardır. ${ }^{5} \mathrm{Bu}$ sebeple, ortak çıkar

Bu perspektifle Ortadoğu'daki ittifak dinamiklerini ele alan bir yazı için bkz. Furkan Polat, "Ortadoğu'daki Yapısal Değişimin Devletlerin İttifak Politikaların Etkisi: Suriye Örneği,” Türkiye Ortadoğu Çalışmaları Dergisi 4, no. 1 (Haziran 2017): 74-102.

2 Hans J. Morgenthau, Politics Among Nations: The Struggle for Power and Peace, (Beijing: Pekin University Press, 1997), 202.

3 Stephen M. Walt, "Why Alliances Endure or Collapse," Survival: Global Politics and Strategy 39, no. 1 (1997): 162.

4 Gideon Rose, "Neoclassical Realizm and Theories of Foreign Policy," World Politics 51, no. 1 (Ekim 1998): 147.

5 Randolph Siverson ve Harvey Starr, "Regime Change and the Restructuring of Alliances," American Journal of Political Science 38, no. 1 (Şubat 1994): 146. 
etrafinda birleşen en az iki devletin oluşturduğu ittifak ilişkisi, çıkarların tanımının değişmesiyle birlikte üyelerinden birisi için eskisi kadar anlamlı olmayabilir. Devletin temel değerlerinde böylesine önemli kırılmaların meydana gelebilmesi bir takım gelişmelerin sonucunda gerçekleşir. $\mathrm{Bu}$ gelişmeler, rejim değiş̧ikliğinin meydana gelmesi, lider değişikliğinin yaşanması, travmatik bir olayın deneyimlenmesi ve iktidarın bir meşruluk krizi içine girmesi şeklinde sıralanabilir. Soğuk Savaş süresince, Irak, Mısır ve İran'da meydana gelen gelişmelere ve mevcut ittifaklarından ayrılış tarihlerine baktığımız zaman aralarındaki neden-sonuç ilişkisi, devletin iç faktörlerinin, mevcut ittifaklarından ayrılışlarına etkisini bir kere daha ortaya koymaktadir.

Makaledeki anlatım yapısı aşağıdaki gibidir. İlk olarak, ittifak literatürünün teorik bir değerlendirmesi yapılmıştır. İttifak literatürünün, devletin iç nedenlerinin ittifak ayrılışına etkisini göz ardı etme eğiliminin eleştirilmesinin yanı sıra ittifak ayrılışına etki eden iç nedenlerin ayrıntılı bir açıklaması yapılmıştır. Daha sonra, iç nedenlerin, devletin ittifak ayrılışı kararını nasıl etkilediği, Irak, Mısır ve İran'ın sunduğu örnek olaylar üzerinden, belirlenen göstergeler kullanılarak incelenmiştir. Ayrıca, inceleme için, Irak, Mısır ve İran'ın neden seçildiği açıklanmıştır. İran ve Irak’tan seçilen örnek olaylar, rejim ve lider değişikliğinin etkisini göstermektedir. Mısır örneği ise travmatik olayın ve meşruluk krizinin ittifak ayrılışındaki etkisini ortaya koymaktadır. Tarihsel akış içerisinde gelişen olaylar, birden fazla iç nedenin etkisi altında kalabilmektedir.

\section{Literatür İncelemesi}

İttifak kavramı, araştırmacılar tarafindan farklılık gösteren kriterlerle tanımlanmaktadır. Kavramı dar anlamıyla kullananlar, en az iki devlet arasında, yazılı anlaşmayla kurulmuş bir ilişki olarak onu değerlendirmiştir. ${ }^{6}$ İttifak ilişkisinin varlığı için yazılı olma durumunu şart koşmayan, ittifak1, iki devletin ortak çıkar ve güvenlik endişesi etrafında birleşerek sürdürdüğü

Brett Leeds, Jeffrey Ritter, Sara Mitchell ve Andrew Long, "Alliance Treaty Obligations and Provisions, 1815-1944," International Interactions: Empirical and Theoretical Research in International Research 28, no. 3 (2002): 238; Glenn Synder, Alliance Politics (Ithaca: Cornell University Press, 2007), 8. 
işbirliği ilişkisi olarak değerlendirenler de vardır. ${ }^{7}$ John P. Miglietta ise ittifakın birçok bileşeni olduğunu ifade eder. En az iki devletten oluşan işbirliği ilişkisi, üye devletlerin askeri güçlerini birleştirmeleri, ortak tehdit algısına sahip olmaları ve dış politika çıkarlarının savunulmasında kolektif hareket etmeleri ittifakın bileşenleri olarak sıralanmıştır. ${ }^{8} \mathrm{Bu}$ tanımlar 1şı̆̆ında, ittifak kavramının en geniş kapsamlı açıklamasının çalışmada kullanılması tercih edilmiştir.

İttifak ayrılışının tespiti için bir takım kriterler belirlenerek standart oluşturulmaya çalışılmıştır. Gösterge olarak adlandırılan bu kriterlerden birincisi, süper güce ait askeri personel sayısındaki değişimdir. ${ }^{9}$ İkincisi ise silah satışını da kapsayacak şekilde süper gücün yaptığı ekonomik-askeri yardımlardaki değişimlerdir. Müttefik devletler, güvenliklerini arttırmak için kabiliyetlerini birleştirme yoluna gittikleri için, ${ }^{10}$ müttefiklik ilişkisi devam ettiği sürece müttefik devlette görevli asker sayısının azalmaması ve yapılan yardımların düşmemesi gerekir. Bu göstergelerdeki kopuş, ittifakın zayıflamakta olduğuna veya sona erdiğine işaret eder. Ayrıca yapılan yardımların, yardım yapılan ülkenin uyumluluğunu sağlayarak iki devlet arasındaki ilişkiyi geliştirmek gibi bir siyasal fonksiyonunun olduğu varsayıldığı için, ${ }^{11}$ bu yardımların azalması ilişkilerin kötüye gidişinin bir belirtisidir. Silah satışı ise devletleri kontrol altında tutmanın aracı olarak kullanışlı bir enstrümandır. ${ }^{12}$ Silah satışı aracılığıyla süper güç müttefiki olan devleti güçlendirir. Devletin ittifaktan ayrılmasından sonra silah satışlarının düşmesi beklenir.

Walt, "Why Alliance," 157; Morgenthau, Politics Among Nations, 202.

John P. Miglietta, American Alliance Policy in the Middle East, 1945-1992: Iran, Israel, and Saudi Arabia, (Maryland: Lexington Books, 2002), 2.

9 Asker gönderiminin ittifak ilişkisine etkisini daha ayrıntılı incelemek için bakınız. Carla Martinez Machain ve T. Clifton Morgan, "The Effect of US Troop Deployment on Host States' Foreign Policy," Armed Force and Society 39, no. 1, (2013): 102-123.

10 Mark J.C. Crescenzi, Jacob D. Kathman, Katja B. Kleinberg, ve Reed M. Wood, "Reliability, Reputation, and Alliance Formation," International Studies Quarterly 56, no. 2 (Haziran 2012): 4.

11 Hans J. Morgenthau, "A Political Theory of Foreign Aid," The American Political Science Review 56, no. 2 (Haziran 1962): 303; Adrienne Armstrong, "The Political Consequence of Economic Dependence," The Journal of Conflict Resolution 25, no. 3 (Eylül 1981): 401-429.

12 John Sislin, "Arms as Influence: The Determinants of Successful Influence," The Journal of Conflict Resolution 38, no. 4 (Aral1k 1994): 681. 
Müttefik süper güçle yapılmış bir anlaşmanın feshedilmesi veya rakip süper güçle yeni anlaşmalar imzalanması bir diğer ittifak ayrılışı göstergesidir. Devletlerin ekonomik ve askeri işbirliklerini kapsayan herhangi bir anlaşma zamanın koşullarının değişmesiyle (rebus sic stantibus) beraber taraflardan birisi için anlamını yitirebilir ve bu devlet anlaşmayı feshedebilir. ${ }^{13} \mathrm{Bu}$ durumu, özelikle yazılı olarak kurulmuş ittifak ilişkilerinde daha net olarak gözlemleyebiliriz. Son gösterge ise müttefik devletten bağımsız politikaların takip edilmesidir. Müttefik olan devletler, pek çok konuda benzer bir tavır sergilemeye eğilimlidir. Bu eğilim, kutuplaşmanın ve taraflar arasındaki çizgilerin net olduğu Soğuk Savaş döneminde daha belirgindir. İttifaktaki zayıf devletin, "patronunu" kızdıracak adımlar atması, müttefiklik ilişkisini gözden çıkardığını ve ittifakı sonlandırdığını göstermektedir.

\section{3. İttifaktan Ayrılışın İç Nedenleri}

İttifak, Uluslararası İlişkiler disiplinindeki önemli kavramlardan birisidir. İttifakların nasıl oluşturuldukları, nasıl sürdürüldükleri pek çok yayına konu olmuş, araştırılmıştır. Bu literatürde ittifakların dağılışını ele alan çalışmalar ise oldukça kısıtlıdır. Bu kısıtlı literatürde yer alan çalışmaların çok az bir kısmı ise devletin iç nedenlerinin, devletin ittifaktan ayrılış kararı üzerindeki etkisini ele alır. ${ }^{14}$ İttifak literatürü üzerinde, realizmin ve neorealizmin belirgin bir ağırlığı söz konusu olduğu için devletlerin ittifak yönelimlerine ilişkin açıklamalar, anarşik uluslararası yapıdaki güç

13 Bruce D. Berkowitz, "Realignment in International Treaty Organizations," International Studies Quarterly 27, no. 1 (Mart 1983): 77.

14 Jack S. Levy, "Domestic Politics and War," The Journal of Interdisciplinary History. 18, no. 4, (Bahar 1988): 653-673; Michael N. Barnett ve Jack S. Levy, "Domestic Source of Alliance and Alignments: The Case of Egypt, 1962-73," International Organization 45, no. 3, (Yaz 1991): 369-395; Randolph M. Siverson ve Juliann Emmons, "Democratic Political System and Alliance Choices in the Twenth Century," Journal of Conflict Resolution 35, no. 2, (Haziran 1991): 285-306; Siverson ve Starr, "Regime Change," 145-161; Stephen M. Walt, "Why Alliances," 156-179; D. Scott Bennett, "Testing Alternative Models of Alliance Duration, 1816-1984," American Journal of Political Science 41, no. 3, (Temmuz 1997): 846-878; Ali Balc1, "A Three Level of Analysis of Turkey's Crisis with the U.S.-led Order," Insight Turkey 21, no. 4, (2019): 13-24. 
ve kapasite dağılımlarıyla ilişkilendirilerek, devletin dışındaki alanlarda cevap aranmıştır. ${ }^{15}$ Uluslararası sistemin yapısı, devletleri belirli yönlere itiyor olsa da sonuçları doğrudan belirlemez. Devletleri etkileyen başka baskı unsurları vardır. ${ }^{16}$ Herhangi bir yapısal değişim olmaksızın, aynı tehdide cevap olarak takip edilen politika tercihleri farklılaşabilir. ${ }^{17} \mathrm{Bu}$ farklılaşmanın açıklanması için devletin içnedenlerinin devletin davranışları üzerindeki etkisine bakılmalıdır. Neoklasik realistler, klasik realistlerin ve neo-realistlerin aksine, araya giren değişkenler olarak tanımladıkları devletin birim düzeyindeki etkenlerini, çalışmalarına dahil ederek daha geniş bir perspektif sunmuşlardır. ${ }^{18}$ Neo-klasik realistler, çalışmalarında ağırlıklı olarak büyük güçlerin düşüş ve yükselişlerini incelemiş olsalar da, ${ }^{19}$ devletin iç değişkenlerini değerlendirmelerinde kullanmaları yol göstericidir. Devletin ittifak ayrılışlarını etkileyen iç nedenlerin ele alındığı bu çalışmada da neo-klasik realizmden faydalanılmıştır.

Devletin hangi ittifaka üye olacağı ya da uluslararası gelişmelere nası1 karşılık vereceği, dış politikanın alanı içindedir. Devletin dış politikasının şekillendirilme süreci, devlet içi unsurların etkisinden arındırılmış değildir. Rejim değişikliği, lider değişikliği, travmatik bir olayın yaşanması ve meşruluk kriziyle karşı karşıya kalınması, devletin davranışlarını, çıkar tanımlamasını etkiler ve buna paralel olarak devletin ittifak tercihleri değişkenlik gösterebilir. ${ }^{20}$

\subsection{Rejim Değiş̧ikliği}

Devletin mevcut iktidarının sahip olduğu ilişkiler ağı, bu iktidarın çıkar

15 Siverson ve Starr, "Regime Change," 147.

16 Jack Donelly, "Realizm," Uluslararası Ilişskiler Teorileri içinde, ed. Scott Burchill ve diğerleri (İstanbul: Küre Yayınları, 2013), 66.

17 James Sperling, "Neo-classical Realism and Alliance Politics," Theorising NATO: New Perspectives on the Atlantic Alliance içinde, ed. Mark Webber ve Adrian HydePrice (New York: Routledge, 2016), 61.

18 Ali Balcı, "Realizm," Uluslararası İlişkilere Giriş: Tarih, Teori, Kavram ve Konular içinde, ed. Şaban Kardaş ve Ali Balcı (İstanbul: Küre Yayınları, 2015), 140-143.

19 Rose, "Neoclassical Realism," 154.

20 Ali Balc1, "A Three Level of Analysis," 13-24; D. Scott Bennett, "Testing Alternative Models," 846-878; Siverson ve Starr, "Regime Change," 145-161; Walt, "Why Alliances," 156-179. 
tanımlamasına, önceliklerine ve tercihlerine dayalı olarak üretilmiştir. Devletin sahip olduğu çıkarlar, doğal olarak belirlenmiş, değişmez unsurlar olmadığı için, toplum içerisinde yer alan farklı sosyal grupların devletin çıkarlarına yönelik tasavvurları farklılık gösterebilir. ${ }^{21}$ Morrow, rejimin siyasal tercihlerinde meydana gelen değişimin mevcut ittifakına ilişkin bakış açısını etkileyeceğini ifade eder. ${ }^{22}$ Çalışmalarında, rejim değişimlerinin ittifak davranışları üzerindeki etkisini ele alan Siverson ve Starr, ittifak değişikliği eğiliminin, rejim değişikliği yaşayan devletlerde, rejim değişikliği yaşamayan devletlerden daha fazla olduğunu ileri sürmektedirler. ${ }^{23}$ Pratik düzlemde ise Soğuk Savaş döneminde ABD ve Sovyetler Birliği sorunlu ülkelerde darbe gibi yöntemlerle rejim değişikliği gerçekleştirerek bu ülkeleri ittifaklarına dahil etmeyi ya da karş1 bloğun ittifakından koparmayı amaçlamıştır. ${ }^{24}$ Öte yandan, yakın siyasal gruplar arasında gerçekleşen bir devir teslim bu sürecin ortaya çıkmasını önleyebilir ve yönetim hala eski "oyunun kurallarıyla" oynamaya devam edebilir. Dolayısıyla bu çalışmada kriter olarak ele alınan rejim değişikliği, hem iktidarın hem de iktidarın "oyun kurallarının" değişmesini ifade etmektedir. ${ }^{25}$

\subsection{Lider Değişikliği}

Ortadoğu'da yer alan devletlerin diğer devletlerle kurdukları ilişkilerin geliştirilmesi ve sürdürülmesi noktasında kişi faktörü önemli bir rol oynamaktadır. ${ }^{26}$ Büyük bir bölümü, Birinci Dünya Savaşı'ndan sonra kurulmuş olan Ortadoğu ülkelerinin, kurumsallaşmış siyasi yapılardan yoksun oluşları da devlet yönetimindeki kişi faktörünün etkisini güçlendirmektedir. $\mathrm{Bu}$ sebeple, devletlerin dış politikadaki adımlarına

21 Walt, "Why Alliances," 162; Siverson ve Starr, "Regime Change," 146.

22 James D. Morrow, "Alliance and Asymmetry: An Alternative to the Capability Aggregation Model of Alliances," American Journal of Political Science 35, no. 4 (Kasım 1991): 917.

23 Siverson ve Starr, "Regime Change," 148.

24 Alexander B. Downes, and Lindsey A. O'Rourke, "You Can't Always Get What You Want: Why Foreign-Imposed Regime Change Seldom Improves Interstate Relations," International Security 41, no. 2 (2016): 43-89.

25 Siverson ve Starr, "Regime Change," 148.

26 Karen Dawisha, Soviet Foreign Policy Towards Egypt (Londra: Macmillan, 1979), 52. 
ilişkin nitelikli bir açıklamanın yapılabilmesi için, karar alıcının etkisi ihmal edilmemelidir. ${ }^{27}$ Liderin dış politika yapımındaki etkisinden yola çıkan çok sayıda çalışma, lider değişikliğinin ilgili devletin dış politikasındaki değişimi nasıl tetiklediğini ortaya koymuştur. ${ }^{28}$

İktidardaki liderin kişisel özellikleri ve sahip olduğu hayat görüşü, devletin izleyebileceği politika seçeneklerini de şekillendireceği için iktidarda meydana gelen değişimler, söz konusu devletin ittifak tercihlerini de etkileyecektir. ${ }^{29}$ Ayrıca liderlerin, bölge üzerinde sahip oldukları nüfuz alanı ve hem kendi vatandaşlarından hem de diğer Araplardan gördükleri teveccüh derecesi farklılaşmaktadır. Bu farklılaşma, liderlerin müttefikleriyle yaptıkları pazarlıklarda masadaki konumlarının da farklılaşmasını doğurur. Müttefikinden talep ettiği destekleri elde etmede başarısızlıkla karşılaşması da yeni liderin farklı ittifak ortağı arayışına yönelmesine yol açabilir. Lider değişikliğinin ittifak ilişkisini etkileyen bir diğer yönü ise, yeni gelen liderin önceki iktidarı yaptığı yardımlarla ayakta tutmuş olan müttefikin samimiyeti ve niyetinden şüphe duyabilecek olmasıdır. ${ }^{30} \mathrm{Bu}$ durum ilerleyen süreçte, farklı partnerle yola devam edilmesine ve yeni bir ilişkiler ağı tesis edilmesine sebep olabilir.

\subsection{Travmatik Olay}

Devletlerin karşı karşıya kaldığı ulusal travma, tüm halk üzerinde yaygın etki yaratan felaket olayı olarak tanımlanmıştır. ${ }^{31}$ Bir topluluğun üyeleri, grup bilincinde silinmez izler bırakan, sonsuza kadar hafizalarında kalacak olan ve gelecek tahayyüllerini kökten ve geri döndürülemez şekilde değiştiren korkunç bir olaya maruz kaldıklarını hissettiklerinde

27 Fareed Zakaria, "Realism and Domestic Politics," International Security 17, no. 1 (Yaz 1992): 197.

28 Örneğin bkz. Ulrich Pilster, Tobias Böhmelt, and Atsushi Tago, "Political Leadership Changes and the Withdrawal From Military Coalition Operations, 1946-2001," International Studies Perspectives 16, no. 4 (2015): 463-483.

29 Siverson ve Starr, "Regime Change," 153.

$30 \quad$ Walt, "Why Alliances," 162.

31 Eliezer Witztum ve Ruth Malkinson, "Death of a Leader: The Social Construction of Bereavement," When Community Weeps: Case Studies in Group Survivorship içinde, ed. Ellen S. Zinner ve Mary Beth Williams (Washington, DC: Taylor \& Francis, 1998), 119. 
ortaya çıkan durum bir travmadır. ${ }^{32}$ Ayrıca, devletin alanı içerisinde, öngörülemeyen ve istenmeyen şekilde ani değişimlerin meydana gelmesi de topluluğu travmatize edici bir durumdur. ${ }^{33}$ Devletlerin uluslararası veya bölgesel gelişmeler sonucunda hayatta kalma (survival) unsurlarının risk altında olması ve bu riskli durumun üstesinden gelebilecek kabiliyet ve kapasiteden yoksun olmaları, bu devletler üzerinde travmatik etkiler bırakmaktadır. Yaşanan olaylar, doğaları gereği travmatik olabilmelerinin yanı sıra içinde gerçekleştikleri sosyal çevrenin yüklediği anlam sebebiyle de travma haline gelebilir ${ }^{34}$ veya sosyal anlam yükleme travmanın şiddetini arttırabilir. Örneğin; devletlerin almış olduğu yenilgiler, varlıklarına tehdit yönelttiği için travmatik bir durum oluştururken, yenilgiyi alan devletin, kendini öncü bir rolde konumlandırmış olması, ulusal travmayı daha da ağırlaştıracaktır.

Travma yaratan olaylara verilecek cevaplar, bu travmaya neden olan koşulların değiştirilmeye çalışılması olacaktır. ${ }^{35}$ Bu sebeple, travma devletin sosyo-ekonomik yapısı üzerinde etkileyici bir güce sahiptir. Daha önceki pratikleri sorgulamaya açar ve değişiklik, yenilik için fırsat sunar. ${ }^{36} \mathrm{Bu}$ dönüşümün devletin ittifak ilişkisini de etkilemesi beklentiler dahilindedir. 11 Eylül saldırılarının dönemin ABD Başkanı George W. Bush üzerindeki etkisini ele alan Jonathan Renshon, söz konusu travmatik olayın başkanın bakış açısını ve dolayısıyla da Amerikan dış politikasının yönünü nasıl değiştirdiğini açık bir şekilde kanıtlamıştır. ${ }^{37}$ Buradan hareketle politik liderlerin ve toplumların deneyimlediği travmatik olayların dış politikada önemli değişiklilere ve daha da önemlisi ittifak ilişkilerinin yeniden düşünülmesine sebep olduğu söylenebilir. Özellikle liderler tarafından mevcut ittifak ilişkisi söz konusu travmatik olayın yaşanmasında önemli bir neden olarak görülüyorsa, bu durum olayın etkisini daha da artırabilir ve ittifaktan ayrılmaya kadar varabilir.

32 Jeffrey C. Alexander, "Towards a Theory of Cultural Trauma," Cultural Trauma and Collective Identity içinde, ed. Jeffrey C. Alexander ve diğerleri (Londra: University of California Press, 2004), 1.

33 A.g.e., 2.

34 A.g.e., 8.

35 A.g.e., 3.

36 Arthur G. Neil, National Trauma and Collective Memory: Major Events in the American Century, (New York: M. E. Sharpe Inc, 1998), 18.

37 Jonathan Renshon, "Stability and Change in Belief Systems: The Operational Code Of George W. Bush," Journal of Conflict Resolution 52, no. 6 (2008): 820-849. 


\subsection{Meşruluk Krizi}

Neo-klasik realistler, devletin birim düzeyindeki gelişmelerinin, devletin davranışlarını etkilediğini savunmaktadır. Dış güvenlik tehditlerini bertaraf etme amacının yanı sıra iç tehditleri önleme çabası da ittifak kararları üzerinde etki sahibidir. ${ }^{38}$ Anarşik uluslararası sistemde hayatta kalmak için mücadele eden devletler, iç siyasetlerinde de benzer bir mücadele içindedirler. Devletler arasında hayatta kalma mücadelesinin yerini, bu kez iktidarda olanın iktidarda kalma mücadelesi alır. Bu mücadelede iktidarın elini zayıflatan, sahip olduğu ittifakın halk nezdindeki meşruluğu azaltan ekonomik ve siyasal tabanlı bir takım gelişmeler, iktidarı yeni yollar denemeye yönlendirebilir.

Ekonomik ve siyasal talepler, ittifak kararlarını şekillendirecektir. ${ }^{39}$ Ekonomik koşulların kötüleşmesi, halkın beklentilerini karşılamada iktidarın yetersiz kalışı, iktidar üzerindeki baskıyı arttıran unsurlardır. Herhangi bir devlet, bu baskının üstesinde gelebilmek için müttefikinin desteğine ihtiyaç duyuyorken bu desteği elde edemezse, iktidarın sahip olduğu ittifak ilişkisi sorgulanır. İttifaklar, ekonomik işbirliğini de kapsayan bir takım beklentilerle kurulduğu için tarafların beklentilerinin karşılanıyor olması ittifakın sürdürülmesinde önemli bir rol oynamaktadır. Mevcut ittifak halkın yaşam standartlarında bir iyileşmeyi beraberinde getirmiyor ve işler daha da kötüleşiyorsa ittifakın itibarı zedelenecektir. İktidar, söz konusu ittifakın sürdürülmesinin maliyetini üstlenmekten kaçabilir.

Siyasi olarak ise süper güç ve küçük devlet arasındaki ittifakın asimetrik doğası, iktidar için sorun yaratabilmektedir. Bağımlılık okulu düşünürleri ve neo-Marksistler, asimetrik ilişkinin söz konusu olduğu durumlarda bağımlılığın olumsuz sonuçlarının daha büyük olduğunu ileri sürmektedirler. ${ }^{40}$ Asimetrik ilişkinin bağımlı durumundaki devleti, daha güçlü olan hamisinin manipülasyonuna veya zorlamasına maruz kalabilir. ${ }^{41}$

38 Steven R. David, "Explaining Third World Alignment," World Politics 43, no. 2 (January 1991): 245.

39 Anessa L. Kimball, "Political Survival, Policy Distribution, and Alliance Formation," Journal of Peace Research 47, no. 4 (2010), 407.

40 Katherine Barbieri, "Economic Interdependence: A Path to Peace or a Source of Interstate Conflict?," Journal of Peace Research 33, no. 1 (Şubat 1996), 32.

${ }^{41}$ Robert O. Keohane ve Joseph S. Nye, "Power and Interdependence," Survival: Global Politics and Strategy, 15, no. 4 (1973), 160. 
$\mathrm{Bu}$ durumda manipülasyon ve zorlamanın sebep olduğu egemenlik ihlali iç siyasette gerilim yaratarak ittifakın gözden düşmesine neden olabilir. İç siyasette güç için rekabet eden elitler, bu durumu kullanabilir. ${ }^{42} \mathrm{Bu}$ durumun, kendisine karşı kullanılması halinde iktidar rakip grubun siyasi yıpratmalarından kurtulmak adına ittifak ilişkisini bozabilir ya da aksine egemenlik ihlali sebebiyle ittifakı hedef göstererek kendi popülaritesini arttırmayı deneyebilir. İç siyasette önemi azalan ittifak ilişkisinin gözden çıkarılması muhtemeldir. ${ }^{43}$ Bazı durumlarda, dış politika adımları, ülke içerisindeki çeşitli grupların desteği devşirmek amacıyla atılabilir. Bunlar, iç politikanın dış politikayı etkilediğinin işaretleridir. ${ }^{44}$

\section{Soğuk Savaş Dönemi Irak, Mısır ve İran Örnekleri}

Ortadoğu bölgesi, Soğuk Savaş'ın süper güçleri, ABD ve Sovyetler Birliği arasındaki rekabetin önemli sahnelerinden birisi olmuştur. ${ }^{45}$ Ortadoğu bölgesinin istikrarlı olmayan bölgesel güç dengesi ve iki süper gücün, rakibinin yayılmasını önleme çabası, dönem boyunca pek çok ilişki kombinasyonunu beraberinde getirmiştir. Ortadoğu bölgesinin, Soğuk Savaş dönemi siyasi tarihinin sunduğu örnek çeşitliliği, hipotezlerin daha sağlıklı bir şekilde test edilmesine imkan sağlamasının yanı sıra sonuçlara ilişkin güvenilirliği de arttırmaktadır. Değerlendirme için bu bölgeden seçilen üç ülke, Irak, Mısır ve İran, küresel düzeyde etki alanları sınırlı olan küçük devletler olsalar da bölgesel olarak değerlendirildiklerinde stratejik öneme sahiptirler. Soğuk Savaş süresince müttefik oldukları süper gücün, rakibini çevreleme planları için önemli roller üstlenmiş ülkelerdir. Bunun yanı sıra, pek çok darbeye maruz kalmaları, rejim ve lider değişimi yaşamaları sebebiyle siyasal hayatları istikrarsılılı, rekabet dolu olmuştur. Düşük ekonomik gelişmişlik seviyesinde olmalarının yanı sıra ekonomik gelişme trendlerinde istikrar söz konusu olmamıştır. Örnek ülkelerin yukarda ifade edilen nitelikleri sebebiyle sıklıkla değişen devlet içi koşullar, devletin ittifak ayrılışı kararına devletin iç koşullarının etkisinin değerlendirilebilmesi için pek çok örneklem sunmaktadır.

\footnotetext{
42 Walt, "Why Alliances," 161.

43 Balc1, "A Three Level of Analysis," 16.

44 Zakaria, "Realism," 198.

45 Peter Mangold, Superpower Intervention in the Middle East (New York: Routledge, 2013), 22.
} 


\subsection{Irak: 1958 Darbesi}

Birinci Dünya Savaşı'ndan sonra Britanya'nın mandası altında varlığını sürdüren Irak, bağımsızlı̆̆ını kazandıktan sonra bile Britanya'nın etkisi altında kalmaya devam etmiştir. 1941 yılında Raşit Ali hükümetinin, Britanya'nın Irak topraklarını kullanma karşılığında askeri destek sağlama teklifini reddedip, Basra'daki Britanya askerlerinin ülkeyi terk etmesini istemesi üzerine Irak ve Britanya arasında bir savaş ortaya çıkmıştır. Savaşın sonucunda Britanya ülkedeki hakimiyetini pekiştirmişken Raşit Ali ve taraftarları ülkeyi terk etmiştir. Bu savaş, Irak'ın bağımsızlığına gölge düşürmesinin yanı sıra Irak'ın Britanya'nın çıkarlarını tehdit edemeyeceğini göstermiştir. ${ }^{46}$ Öte yandan, kitle iletişim araçları, gazete ve radyonun yayılması, eğitim olanaklarının genişlemesiyle birlikte dünyayla iletişimi artan insanların beklentileri yükselmekteydi. Daha fazla bireysel özgürlük, daha eşitlikçi toplum ve Batı etkisinden daha bağımsız bir ülke talepleri vardı. Anti-emperyalizm ve rejimin dış bağlantısının koparılması muhalefetin ortak noktası olmuştur. ${ }^{47}$

General Abdülkerim Kasım önderliğinde 14 Temmuz 1958'de gerçekleştirilen darbeyle birlikte Irak monarşisi sonlandırılmıştı. Darbeyi gerçekleştiren genç subaylar, 1941'de yarım kalan işi tamamladıklarına inanmıştır. ${ }^{48}$ Kral II. Faysal, Prens Abdullah ve İngilizlerin adamı olarak görülen Başbakan Nuri Said öldürülmüş; Cumhuriyet ilan edilerek yeni bir rejim kurulmuştur. Darbeden sonra Irak, Batı bloğundan uzaklaşarak Doğu bloğuyla yakınlaşmıştır. ${ }^{49}$ Irak, 1955 yılında Irak, İngiltere, İran, Türkiye ve Pakistan arasında kurulan Bağdat Paktı'ndan, Mart 1959'da ayrıldığını açıklamış; bu karar, Batı'yla yaşanan ayrılığın simgesi haline gelmiştir.

Soğuk Savaş döneminin başlangıcından itibaren Irak'ta ABD'nin askeri varlığı mevcut olmuştur. ABD'nin görevlendirdiği asker sayıs1, 1953 'ten itibaren ise sürekli olarak artmıştır. 1958'de zirve noktasını (60) gördükten sonra 1959'da ciddi bir düşüşle (24) karşılaşmıştır. Üstelik bu askeri personel sayısındaki düşüş eğiliminin, geçici bir trend olmayıp istikrarlı

\footnotetext{
46 Tayyar Ar1, Geçmişten Günümüze Ortadoğu Siyaset, Savaş ve Diplomasi (Bursa: Dora Yayınlar1, 2014), 453-4.

47 Phebe Marr, The Modern History of Iraq (Colorado: Westview Press, 2012), 61-2.

48 Marr, The Modern History of Iraq, 56.

49 Ar1, Geçmişten Günümüze Ortadoğu, 456.
} 
bir süreklilik gösterdiği grafikte görülmektedir. Bu yönüyle Grafik 1'deki veriler, ${ }^{50}$ Irak' $1 n$ Batı'yla kurduğu ittifaktan ayrıldığı iddiasını destekleyici niteliktedir.

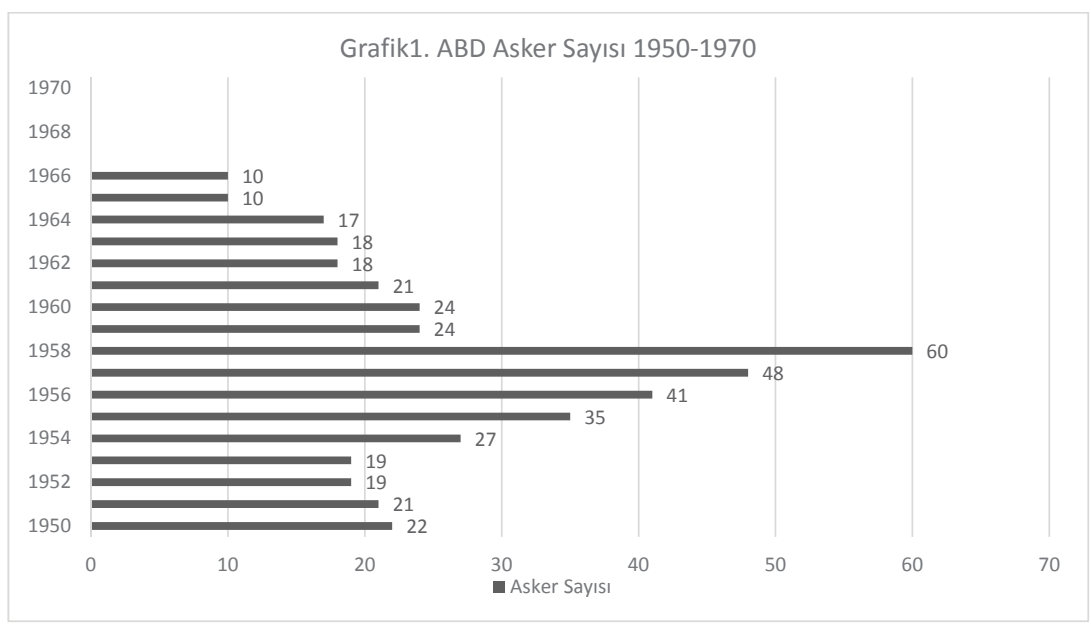

Grafik 2'de yer alan, süper güçlerin Irak'a yaptığı ekonomik ve askeri yardıma ilişkin veriler, ${ }^{51} 1958$ ' den sonra ABD'nin yardımlarında yaşanan düşüşün, Sovyetler Birliği'nden alınan yardımlarla dengelendiğini göstermektedir. Müttefik devletler arasındaki iş bölümünün bir tezahürü olan dış yardım uygulamalarındaki bir düşüş, müttefiklik ilişkisinin kötü gidişatının bir işarettir. ${ }^{52}$ Müttefik süper gücün yardımındaki düşüşün rakip süper güçten alınan yardımla kapatılması, Irak'ın Batı'dan kopuşunun ve Doğu'yla yakınlaşmasının somut bir ifadesidir.

50 Tim Kane, "Global U.S. Troop Deployment 1950-2005," A Report of the Heritage Center for Data Analysis, (Washington D.C.:The Heritage Foundation, 2006).

51 USAID Data Service, US Overseas Loans and Grants [Greenbook], Washington D.C., 2019; James Richard Carter, The Net Cost of the Soviet Foreign Aids, (New York: Praeger, 1971), Aktaran Gu Guan-Fu, "Soviet Aid to the Third World an Analysis of Its Strategy," Soviet Studies 35, no. 1 (Ocak 1983), 75.

52 Morgenthau, "A Political Theory," 303. 


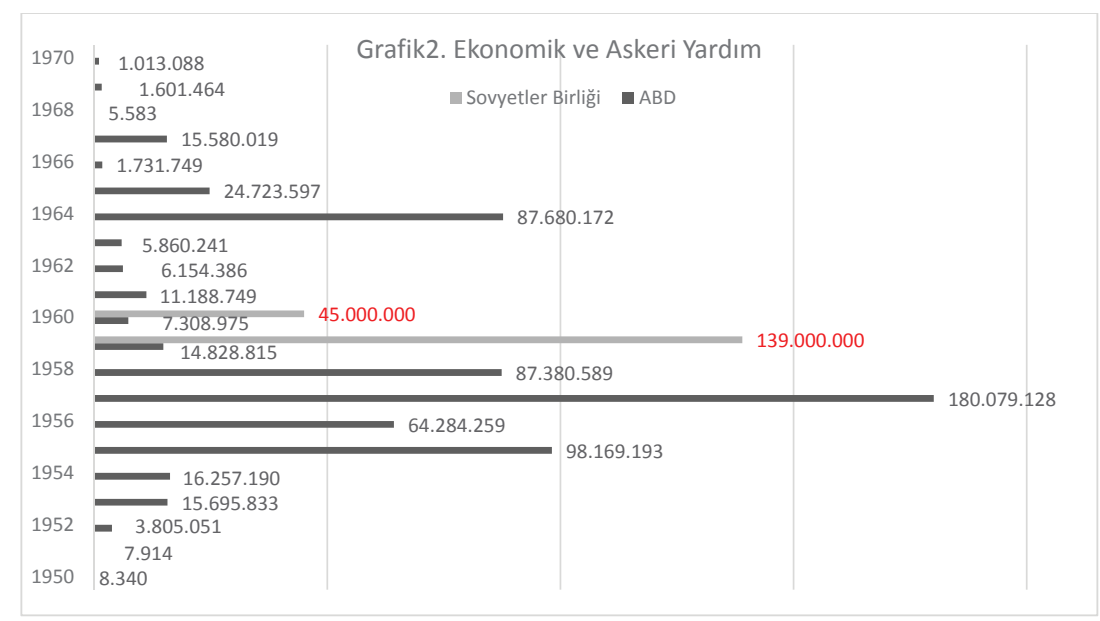

İttifak ayrılışının ikinci göstergesinin bir diğer parçası olan silah ticaretine ilişkin verilere ${ }^{53}$ baktığımızda Irak'ın 1957 y1lına kadar sadece Batı bloğu ülkelerinden alım yaptığını görmekteyiz. Darbenin gerçekleştiği 1958 y1lından 1963 y1lına kadar ise sadece Doğu bloğu ülkeleriyle silah alışverişi yapmıştır. 1958 yılı, Irak'ın silah ticaretindeki net bir kırılmayı işaret etmektedir. Güvenlik endişesi ittifak oluşumunun önemli motivasyonlardan birisiyken, ${ }^{54}$ ulusal güvenliği sağlamanın ve caydırıcılık oluşturmanın etkili bir aracı olan silahların temini de büyük ölçüde müttefik güçten yapılır. 1958 yılından 1964 yılına kadar Sovyetler Birliği dışında herhangi bir Batı bloğu ülkesinden silah ve mühimmat alışverişi yapılmamış olması da Irak'ın ittifak tercihindeki değişimin bir sonucu olarak değerlendirilebilir.

53 SIPRI, Arms Trade Database, 2019, http://armstrade.sipri.org/armstrade/page/trade register.php (7 Temmuz 2019)

54 Walt, "Why Alliances," 157. 


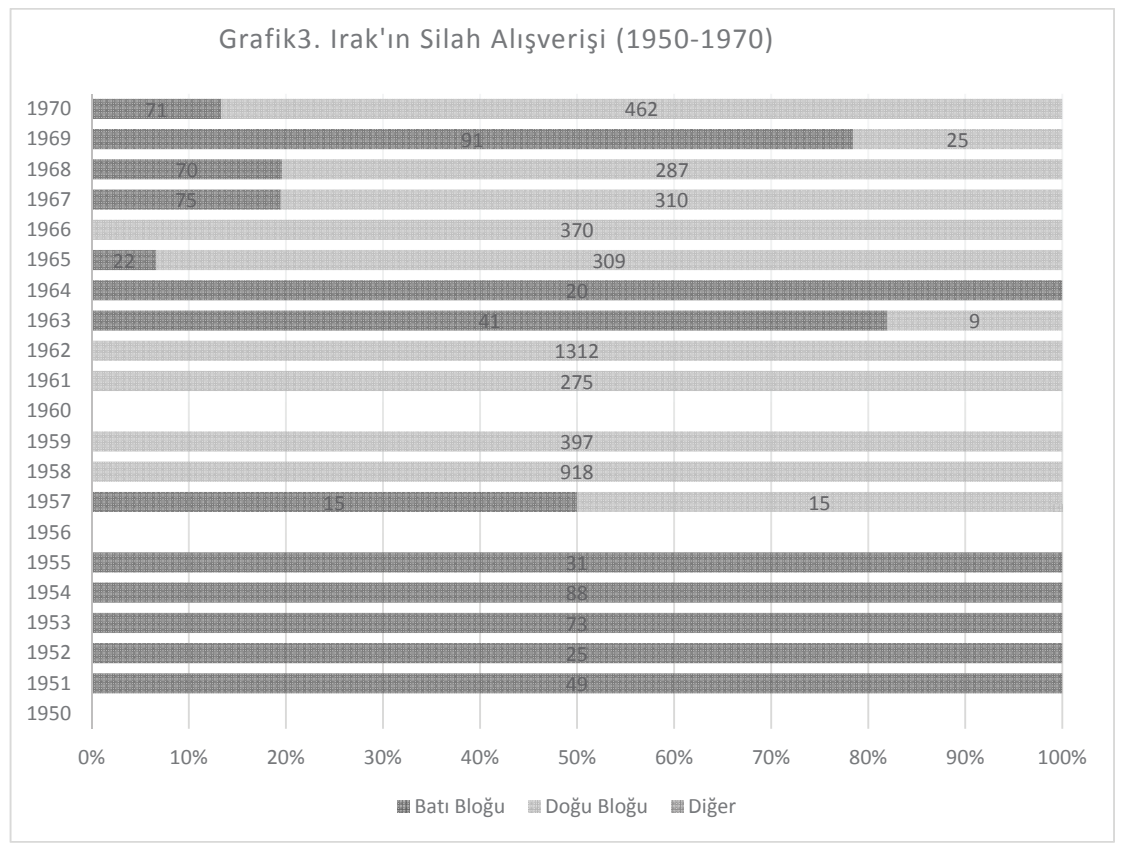

Irak, ABD’nin Soğuk Savaş döneminde rakibi Sovyetler Birliği'ni çevrelemek için hayata geçirdiği paktlar sisteminin parçası olan Bağdat Paktı'nın bir üyesiydi. ABD, paktın içinde gözlemci statüsünde yer almaktaydı. Irak, 1958 Darbesinden sonra Bağdat Paktı'ndan ayrılma kararı alarak Batı ile olan (dolayısıyla ABD ile olan) ittifakına son verdiğini ilan etmiştir. Ayrıca darbeden hemen sonra Sovyetler Birliği, Bat1-yanlısı hükümetin devrilmesinde sonra kurulan cumhuriyetçi yönetimi memnuniyetle karşılayarak derhal Irak Cumhuriyeti'ni tanımıştır. Sovyetlerin memnuniyeti, cumhuriyetçi rejimin Batı-karşıtı bir duruşa sahip olmasından kaynaklanmıştır. ${ }^{55}$ Sovyetler Birliği, Batı'dan kopuşuna memnun olduğu Irak'a sadece devleti hızlıca tanımasında gördüğümüz gibi siyasal olarak destek vermemiş, aynı zamanda ekonomik ve askeri alanda da ilişkilerini geliştirmiştir. Irak'la ticari ve askeri anlaşmaların ilkini 1958'in sonunda imzalamıştır. 137 milyon dolar değerindeki bir başka ekonomik yardım anlaşması ise Mart 1959'da imzalanmıştır. ${ }^{56}$ Ayrıca, Irak'ın Bağdat

55 Oles M.Smolansky ve Bettie M. Smolansky, The USSR and Iraq: The Soviet Quest for Influence (Durham ve Londra: Duke University Press, 1991), 15.

56 Smolansky ve Smolansky, The USSR and Iraq, 16. 
Paktı'ndan ayrılması, Sovyetler Birliği'nden diplomatik destek alması, ekonomik ve askeri alanda Sovyetler Birliği ile yüksek meblağlı yardım ve silah anlaşmaları yapması müttefikinden bağımsız politikalar izlemesine örnek gösterilebilecek olaylardır. Irak'ın siyasi, askeri ve ekonomik politikalarının yön değiştirdiği ve yeni bir eğilime yöneldiği sonucu açıkça görülebilmektedir.

1958 y1lında Irak'1 darbeye götüren süreç, halkın talep ve beklentilerine ilgisiz yönetimlerin ortak kaderi olmuştur. Britanya'nın etkisi altındaki monarşinin sosyal tabanı, geniş toprak sahiplerinden geliyor; bu toprak sahipleri ve onların yarattığı sosyo-ekonomik yapılar, tarım alanındaki değişim süreçlerini çarpıtma ve durdurma etkisine sahip oluyordu. Tarımdan elde edilen kar, toprak sahiplerini zenginleştiriyorken köylünün borcu gittikçe yükselmekteydi. Bu durum Britanya'nın bilinçli tercihlerinin sonucuydu. Tarım sektöründe kalarak borçlarını kapatmayı başaramayan köylüler, petrolün sağladığı iş olanaklarına güvenerek şehirlere göç etmeye başlamışlard1. ${ }^{57}$ Bağdat'ın nüfusu 1950-1958 arasında 579.000'den 847.000'e çıkarak \%46 yükselmişti. ${ }^{58}$

Nispeten iyi eğitim almış olan küçük burjuvazi mensupları, milliyetçi ve anti-emperyalist düşüncelerin taşıyıcısı durumundaydılar. Monarşiye ve var olan siyasal yapıya, Britanya'nın çıkarlarına hizmet ettikleri gerekçesiyle karşı çıkmışlardır. ${ }^{59}$ Rejim yeni yükselen bu toplumsal sınıfın desteğini kazanmakta başarılı olamamıştır. ${ }^{60}$ Bunun sebebi, 1955 yılında, Nuri Sait Paşa'nın Bağdat Paktına katılmasında da gördügümüz gibi halkın tepkilerini görmezden gelmesi olmuştur. Ayrıca, Mısır'ın müttefiki Sovyetler Birliği'nden büyük miktarlarda aldığı modern silahların, Irak'ın müttefikinden aldığı silahlarla kıyaslanması, Nuri Said'in Irak için en iyisini yapıp yapamadığını sorgulatmıştır. ${ }^{61}$ Monarşinin son yıllarında,

57 Marion Farouk-Sluglett ve Peter Sluglett, Iraq Since 1958:From Revolution to Dictatorship (New York: I.B.Tairus and Co Ltd.,2001), 31-34.

58 Baghdad, Iraq Population 1950-2020, https://www.macrotrends.net/cities/21529/ baghdad/population (7 Mart 2020)

59 Farouk-Sluglett ve Sluglett, Iraq Since 1958, 36-37.

60 Marr, The Modern Histıry of Iraq, 78.

61 Hanna Batatu, The Old Social Classes and the Revolutionary Movements of Iraq: A Study of Iraq's Old Landed and Commercial Classes and of its Communists, Ba thists, and Free Officers (New Jersey: Princeton University Press, 1978), 766. 
toplumun bütün kesimleri, ülkenin en acil ihtiyacının ulusal bağımsızlık ve ekonomik gelişme olduğu düşüncesinde hem fikir olmuştur. ${ }^{62}$

Irak’ta 1932-1958 yılları arasında on dokuz başbakan görev yapmıştır. 1958 yılında başbakan olan Nuri Said, 8. kez başbakan olmuştur. İstikrarsız siyasal koşullar ve iktidarın güç kullanma tekeli karşısında muhalif politikacıların güçsüzlüğü, rejimi devirmenin ancak güç kullanılarak mümkün olabileceğini göstermekteydi. ${ }^{63}$ Diğer devlet kurumlarının aksine ordu mensupları, büyük ölçüde alt ve orta sınıftan geliyorlard1. ${ }^{64}$ Çünkü eğitim veya ordu kariyeri, soylu aileden gelmeyen ve servet sahibi olmayan bireyler için sosyal sınıf atlama imkanı sunuyordu. Ordudaki genç jenerasyon, farkl1 farklı sosyal gruplardan geliyordu ve onların düşünce yapıları, komünizm, Nasırcılık ya da pan-Arabizmin diğer versiyonları da dahil olmak üzere ülkede yayılan çeşitli siyasal akımlardan etkilenmekteydi. ${ }^{65}$

Ordu içerisinde Hür Subaylar olarak örgütlenen yaklaşık 200 kişilik bir grup, tek bir olaya verilen ani bir tepkiyle değil süreç içerisinde yavaş yavaş biriken duyguların eseri olarak ortaya çıkmışt1. ${ }^{66}$ Homojen bir grup söz konusu değildi fakat ortak bir amaçları vardı; rejimi yıkmak. Bu amaca ulaşıldıktan sonra, heterojen yapıdaki grup içinde izlenecek politikalar hakkında görüş ayrılıkları ortaya çıkmış olsa da Irak milliyetçisi kanadı temsil eden ve 1957 yılında grubun başkanı olan Abdül Kerim Kasım ağır basan taraf olmuştu. Diğer grup ise Abdül Selam Arif'in temsil ettiği panArabizmi savunanlar olmuştur. ${ }^{67}$

Darbeden sonra ilk iş, eski rejimin kurumlarının (monarşi ve parlamento) ortadan kaldırılması ve bu kurumlarla ilişkili kişilerin temizlenmesi olmuştur. Ordudan, polisten, kamu hizmetlerinde çalışanlardan pek çok kişi tasfiye edilmiş ve devrime sadık kişiler onların yerlerine yerleştirilmiştir. Devrilen monarşinin yerine Irak Cumhuriyeti ilan edilmiş; Abdül Kerim Kasım, Irak'1n ilk cumhurbaşkanı olmuştur. Ekim 1958'de geniş kapsamlı

\footnotetext{
62 Farouk-Sluglett ve Sluglett, Iraq Since 1958, 37-38.

63 Farouk-Sluglett ve Sluglett, Iraq Since 1958, 45.

64 Batatu, The Old Social Classes, 764.

65 Farouk-Sluglett ve Sluglett, Iraq Since 1958, 44-45.

66 Batatu, The Old Classes, 765; Farouk-Sluglett ve Sluglett, Iraq Since 1958, 48.

67 Farouk-Sluglett ve Sluglett, Iraq Since 1958, 51-53.
} 
toprak reformu başlatılmıştır. $\mathrm{Bu}$, eski rejimin toplumsal tabanını temsil eden geniş toprak sahibi kesimin siyasal gücünü kırmayı amaçlayan bir adım olmuştur. ${ }^{68}$

Yukarıda açıklanan göstergeler bir bütün olarak değerlendirildiğinde veriler birbirini tamamlayıc1 ve destekleyici mahiyettedir ve Irak'1n 1958 Darbesi'nden sonra Batı ittifakından ayrılışına işaret etmektedir. 1958 yılında ordu mensuplarınca gerçekleştirilen darbe, Irak'ın çıkarlarına hizmet etmediği düşünülen monarşiyi ortadan kaldırmayı amaçlamıştır. Eski rejimin kurduğu sosyo-ekonomik yapının önemli unsuru olan geniş toprak sahibi kişiler de darbenin hedefinde olmuştur. Toplumun alt ve orta gelir grubu, küçük burjuvazi tarafından desteklenen darbe, sosyalist düşünceye yakın durmuştur. Darbeden kısa bir süre sonra Sovyetler Birliği, Çin ve diğer sosyalist devletlerle ilişkiler kurulması, yeni yönetimin Britanya ve Batı' dan bağımsız dış politika izleme arzusunun işaretleri olmuştur. ${ }^{69}$

1958 Darbesi Irak'ın rejimini ve liderini değiştirmiş; General Abdül Kerim Kasım, Irak milliyetçisi bakış açısıyla iktidardaki kişi olmuştur. Darbeden sonra ortaya çıkan, Kasım ve Arif arasındaki güç mücadelesi devletin inşasındaki lider faktörünü göstermesi açısından değerlidir. Rejimin değişmesini sağlayan darbeyi birlikte başaran Kasım ve Arif, devletin inşasına dair farklı bakış açılarına sahiplerdi. Arif, pan-Arabizmin etkisinde olarak Suriye ve Mısır'la birleşme hayali kurmaktayken, Kasım bir Irak milliyetçisi olarak bu fikre kesin olarak karşı çıkmıştır. Yeni rejimin, devletin uluslararası konumunu, çıkarlarını ve ideolojisini tanımlamasında bu farklılığın yansımasını görmekteyiz. Darbeden sonra yönetimi ele alan General Abdül Kerim Kasım öncülüğünde Irak, Batı ittifakından ayrılarak, Doğu Bloğu'yla ilişkilerini geliştirmeye yönelmiştir. Bu olay, devletin yeniden inşasının yolunu açan rejim ve lider değişikliğinin, devletin çıkarlarını, beklentilerini revize ederek ittifak tercihlerini etkilediğini göstermektedir.

\subsection{Mısır: 1967 Savaşı ve 1973 Savaşı}

Mısır, Nasır'ın aktif dış politikasının bir sonucu olarak Ortadoğu'daki birçok olayın merkezinde konumlanmıştır. Süveyş Krizi'nin sağladığı

68 Marr, The Modern History of Iraq 81.

${ }_{69}$ Farouk-Sluglett ve Sluglett, Iraq Since 1958, 51. 
prestij, Nasır'1 Arap halkları nezdinde lider pozisyonuna taşımıştır. $\mathrm{Bu}$ rolün, Nasır'a yüklediği sorumluluk Misır'1 kapasitesinin üstünde sorunlarla karşı karşıya bırakmıştır. 1967 yılında Mısır öncülügündeki Arap koalisyonu, ağır bir İsrail yenilgisi yaşamış; Sovyetler Birliği’nin yıllardır devam eden askeri ve ekonomik yardımlarına rağmen Mısır'ın kendisini savunamayacak durumda olmasının ortaya çıkması Sovyetler Birliği ittifakını sorgulamaya yöneltmiştir. $\mathrm{Bu}$ gerçekle yüzleşmenin travması, Nasır'ı ABD'yle ilişkilerini yenileme yoluna götürmüş olsa da girişimlerden bir sonuç alınamamıştır.

Alternatif üretmede başarısız olan Misır, Sovyetler Birliği'yle gittikçe daha fazla bağımlı hale geldiği bir ilişkiye girmiş; bu bağımlılık, hem Sovyetler Birliği'nin her problemin sebebi olarak görülmesine ve sorumlu tutulmasına hem de halkın ittifakı egemenliğinin ihlali olarak görmesine yol açmıştır. Ayrıca, Enver Sedat, Nasır'ın sahip olduğu karizmadan yoksun olduğu için Sovyetler Birliği ile yaptığı pazarlıklarda taleplerini elde etmekte zorlanmıştır. Sovyetler Birliği'nin iki lidere dair bakış açısı farklı olmuştur. Enver Sedat dönemi boyunca gerilimin eksik olmadığ Sovyetler Birliği-Mısır ilişkisi, Sedat'ın 1976 yılında Dostluk ve İşbirliği Anlaşması'nı fesih ettiğini açıklamasıyla resmi olarak sona ermiştir.

Soğuk Savaş boyunca Mısır topraklarında ABD askerleri görev yapmıştır. Sovyetler Birliği'nin görevlendirdiği asker sayısı hakkında bilgi sahibi olmamakla birlikte 1972 y1lında Sedat'in talimatiyla Sovyet askeri personellerinin ülkeden çıkarılmasından sonra on beş bin dolayındaki askeri personel sayısının bine kadar düştüğü kabul edilmektedir. ${ }^{70}$ Fakat ABD askerinin sayısı, 1973 yılından itibaren önemli ölçüde artmıştır. 1980'lerde Misır'da on bir binden fazla ABD askeri bulunmaktaydı.

70 Dawisha, Soviet Foreign Policy, 63-64. 


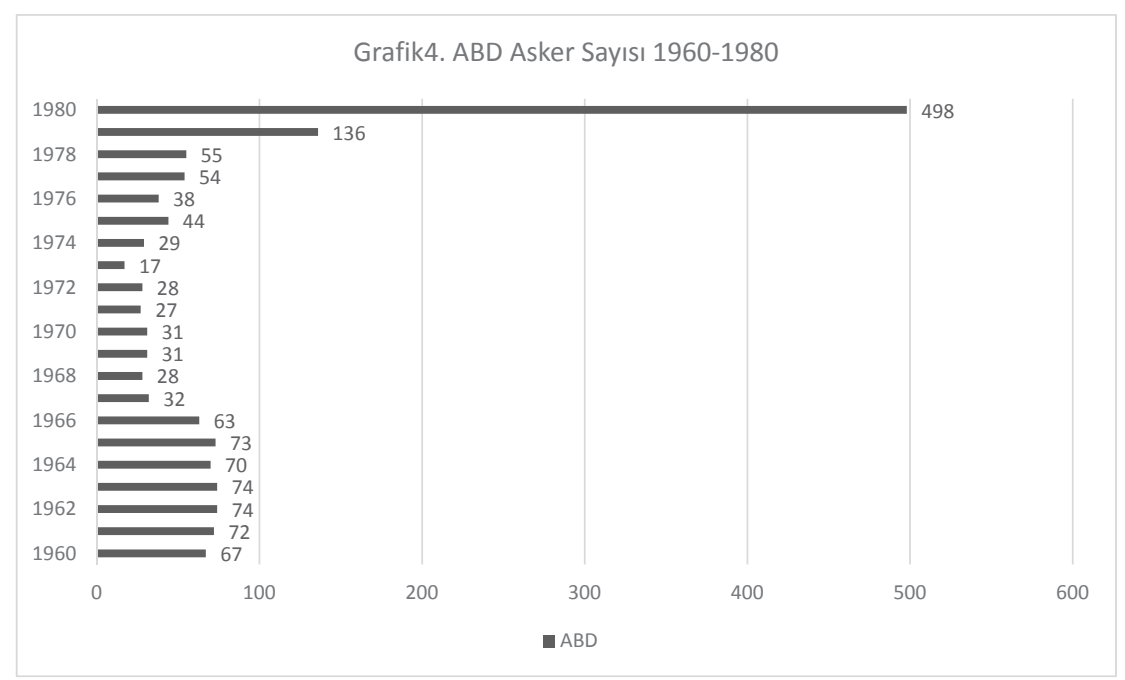

İttifak ilişkisinin önemli parçası olan ekonomik ve askeri yardımların grafiği, Misır'ın 1973'ten sonra katlanarak artan miktarlarda Amerika'dan yardım aldığını göstermektedir. Sovyetler Birliği'nin yardımlarına ilişkin bir kaynak bulunmayışı bir eksiklik olsa da Amerika'nın yapmış olduğu yardım miktarları ittifak ilişkisinin varlığı noktasında şüphe bırakmamaktadır. Yabancı Askeri Yardım Fonu (FMF), Ekonomik Destek Fonları (ESF) ve Uluslararası Askeri Eğitim ve Öğretim Programı (IMET), Mısır'ın faydalandığı başlıca yardımlardır. ${ }^{71}$

71 Jeremy M. Sharp, "Egypt: Background and US Relations," CRS Report, (Washington: Congressional Research Service, 2019), 22. 


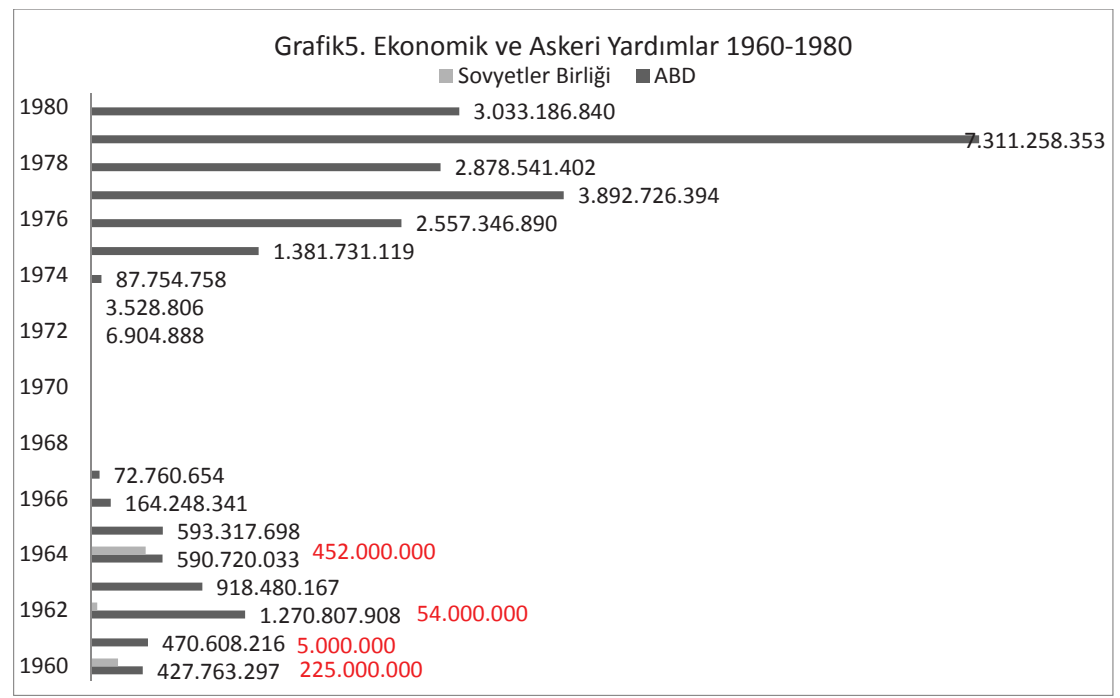

Silah temini konusunda Mısır için Sovyetler Birliği'ne ciddi oranda bir bağımlılık söz konusu olmuştur. Mısır'ın 1963-1975 y1lları arasında gerçekleştirdiği silah alımlarının \%89,7'si Sovyetler Birliği'nden yapılmıştır. ${ }^{72}$ Silah alımı, Enver Sedat'ın iktidarından önce \%100 oranında Doğu Bloğu ülkelerinden gerçekleştiriliyorken, 1971 yılından itibaren Batı ülkelerinden de alıma başlanmış ve 1973 yılından sonra silah alımında Batı'nın payı katlanmıştır. Ayrıca, 1972 yılında Sedat'ın Sovyet askerlerini ülkeden göndermesiyle beraber, avcı uçağı, hava savunma füze bataryaları gibi gelişmiş silahların da Mısır'dan çekildiği kabul edilmektedir. ${ }^{73}$ Müttefik devletlerden güçlü olanın zayıf olanı desteklemesi ittifaktaki iş bölümünün bir parçası olarak olağan bir durumdur. ${ }^{74}$ Desteğin geri çekilmesi, ittifak ilişkisinde çatırdamanın mevcut olduğunu gösterir.

72 Alexander J. Bennett, "Arms Transfers as an Instrument of Soviet Policy in the Middle East," Middle East Journal 39, no. 4 (Illkbahar 1985): 752.

73 Dawisha, Soviet Foreign Policy, 63-64.

74 Morgenthau, "A Political Theory," 303. 
Küçük Devlet Neden Süper Güç Ittifakından Ayrılır? Soğuk Savaş Dönemi Irak, Mısır...

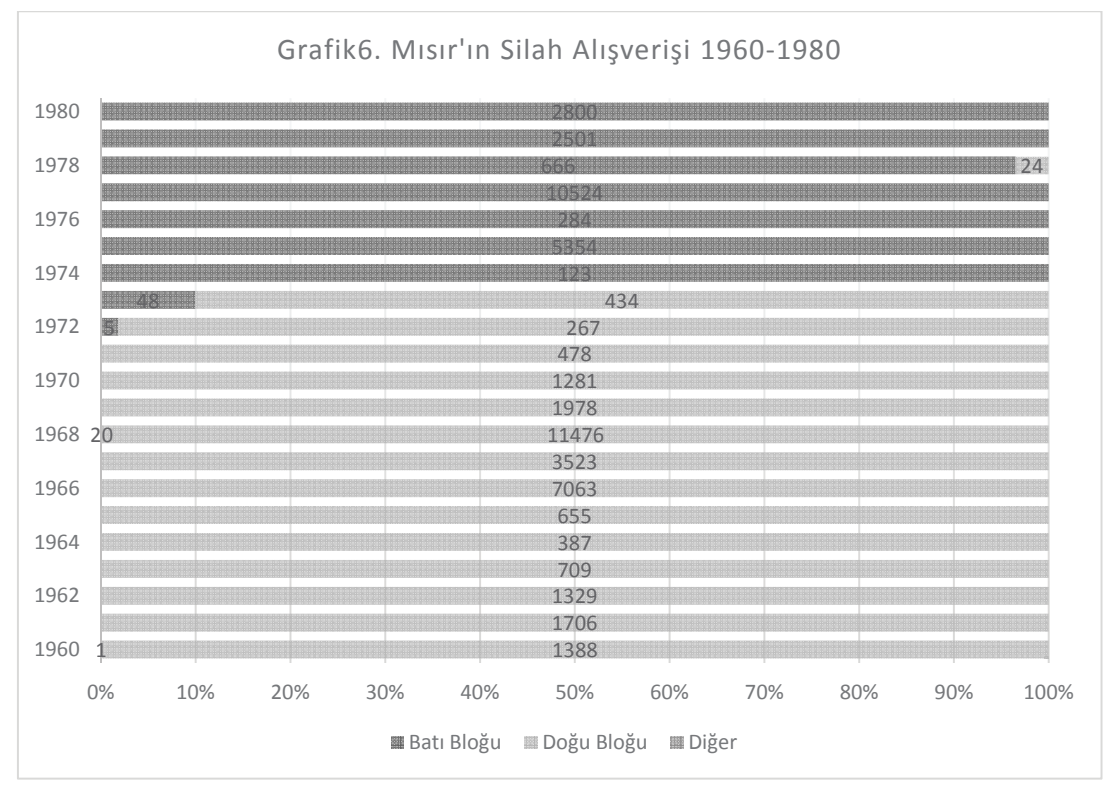

Sovyetler Birliği ve Mısır arasında yazılı olma koşuluna uygun bir ittifak ilişkisi söz konusu olmuştu. Hatta Sovyetler Birliği'nin 1971 yılında Mısır'la imzaladığı anlaşma, Sovyetler Birliği'nin Üçüncü Dünya ülkeleriyle yürüttüğü ilişkisinde bir ilk olmasının yanı sıra gelecekteki ilişkileri için model olmuştur. ${ }^{75}$ Sedat, bu anlaşmay1 15 Mart 1976'da feshettiğini açıklamıştır. Bu durum, Mısır'ın Sovyetler Birliği'yle ittifakını sonlandırdığının net bir ifadesidir.

Son gösterge olan müttefik devletten bağımsız politikalar takip edilmesi koşulunun, Sedat'ın liderliği dönemindeki gelişmelere baktığımız zaman karşılandığını görmekteyiz. Enver Sedat dönemi boyunca Sovyetler Birliği ile ilişkiler gerilimli bir seyir izlemiştir. Mısır, dış politikada müttefikinin aksi yönde girişimlerde bulunmuştur. Örneğin, Mısır, Sudan'da Numeyri taraftarlarını destekleyerek komünistlerin organize ettiği darbenin başarılı olmasını önlemiştir. İktidarını sürdürmeyi başaran Numeyri ise sonraki yıllarda Sovyetler Birliği'nden uzaklaşarak ABD ile yakınlaşmıştır. ${ }^{76} \mathrm{Bu}$,

75 Dawisha, Soviet Foreign Policy, 76.

76 Dennis Hevesi, "Gaafar al- Nimeiry, A Sudan Leader Shifting Politics, Dies at 79," The New York Times, 11 Haziran 2009, https:/www.nytimes.com/2009/06/12/world/ africa/12nimeiry.html 
Sovyetler Birliği adına bir başarısızlık olmuştur. Sovyetler Birliği'nin Sedat'ın komünist darbeyi önlemesinden rahatsız olduğu için Mısır'a yaptığı silah sevkiyatını yavaşlatması Sedat'ın sert tepkisiyle karşılaşmıştır. Sedat'ın Sovyet askeri personelinin ülkeyi terk etmesi çağrısından sonra Mısır'daki Sovyet askeri personel sayısının on beş binden bine düştüğü kabul edilmektedir. ${ }^{77} \mathrm{Bu}$ adımın amaçlarından birisi, Sovyetler Birliği’ne Mısır'ın ihtiyaçlarını karşılama konusundaki yavaşlığının neticelerini göstermekse diğeri de ABD'ye, Mısır'ın Sovyetler Birliği'nden bağımsız hareket edebildiğinin gösterilmesidir. ${ }^{78}$ Ayrıca Mısır, 1973 Ekim Savaşı'ndan sonra İsrail'le barış görüşmelerinin yürütülmesi aşamasında Sovyetler Birliği'ni saf dışı bırakarak ABD aracılığıyla çözüm arayışına girmiştir. Sedat, ABD'nin yürüttüğü çalışmalara olumlu yaklaşarak 19 Kasım 1977'de İsrail'e bir ziyaret gerçekleştirmiş ve İsrail parlamentosu Knesset'te konuşma yapan ilk Arap lider olmuştur. ${ }^{79} \mathrm{Bu}$ sürecin ilerleyen aşamalarında İsrail ve Mısır arasında başlayan ikili görüşmeler, 17 Eylül 1978'de Camp David Anlaşması'nın Enver Sedat, Menahem Begin ve Jimmy Carter tarafından imzalanmasıyla sonuçlanmıştır.

Yukarıda açıklanan göstergeler, Mısır'ın Sovyetler Birliği ittifakından ayrıldığını net bir şekilde ortaya koymaktadır. Mısır örneğindeki ittifak ayrılışının, dikkat çekici bir özelliği bulunmaktadır. Mısır'ın ayrılışı, bir önceki örnek olaydan farklı olarak uzun yıllara yayılan bir süreç içerisinde gerçekleşmiştir. 1967 Savaşı'ndan sonra yaşanan hayal kırıklı̆̆ıyla başlayan bu sürecin, kopuşla sona ermesinde söz konusu sürece etki eden birçok neden bulunmaktadır. Travmatik olay, lider değişikliği ve iktidarın meşruluk krizi ayrılış kararını şekillendirmiştir. Arap devletleri ve İsrail arasında yıllardır süregelen savaşlar, Arap devletlerinin taleplerini elde etmelerine katkı sağlamamıştır. Özellikle 1967 Savaşı, İsrail hava savunmasının kısa sürede Arap devletlerini başarısızlığa uğratması ve geniş toprak kazanımları elde etmesi sebebiyle büyük bir utanç kaynağı olmuştu. Misır da bu travmatik yenilginin mağduru olmuş; bu yenilgi Sovyetler Birliği ile olan ittifakını sorgulamasına yol açmıştır. ${ }^{80}$ Uzun

77 Dawisha, Soviet Foreign Policy, 63-64.

78 William L. Cleveland, Modern Ortadoğu Tarihi (İstanbul: Agora Kitaplığı, 2008), 417.

79 Hilal Görgün, “Enver Sedat,” TDV İslam Ansiklopedisi, 266, https://islamansiklopedisi. org.tr/enver-sedat (13.12.2019).

80 Yehuda U. Blanga, "Nasser's Dilemma: Egypt's Relations with the United States and Israel, 1967-69," Middle Eastern Studies 51, no. 2 (Eylül 2014): 312. 
yıllardır Sovyetler Birliği’nden aldığı askeri ve ekonomik yardımlara rağmen, Mısır'ın, sınırlarını ve toprak bütünlüğünü korumada yetersiz durumda olduğu ortaya çıkmıştır. Ayrıca, 1967 Savaşı'ndan sonra Nasır, Ortadoğu'daki kriz ve sorunların "Amerikan anahtarı" olmaksızın çözümlenemeyeceğini fark etmiştir. ${ }^{81}$ Sovyetler Birliği’nin ABD ve Misır arasındaki flörte kayıtsız kalmayacağını bilmesine rağmen, Nasır ABD ile ilişkilerin kurulmasını sağlayacak alternatif yolları denemiştir. ${ }^{82} \mathrm{Nasır}$, İsrail karşısındaki sorunu çözebilecek kapasiteden yoksun olduğunun ve bu konunun çözümünde Sovyetler Birliği'nin yetersiz olduğunun farkında olarak ABD ile ilişki kurma ve Arap-İsrail konusunda ABD'yi dengeli bir politikaya çekme gayretinde olmuştur. Fakat hem tarafların pozisyonlarında esnekliğe açık olmamaları hem Nasır'ın ABD'nin taleplerini, kendisine atfettiği Arap liderliği rolüyle bağdaştıramaması hem de ABD'deki seçim süreci belirsizliği gibi etkenler sebebiyle bu konuda bir ilerleme kaydedilememiştir. Mısır ve İsrail arasındaki sorun Mısır için problem yaratmaya sonraki yıllarda da devam etmiş̧ir. Nasır gibi, Enver Sedat da İsrail ile yaşadıkları sorunun diplomatik yollardan çözümünde ABD'nin kilit bir role sahip olduğunu fark etmiştir. Fakat ABD'nin İsrail ve Mısır konusuna müdahil olması ancak 1973'teki Ekim Savaşı'ndan sonra mümkün olmuştur. Ekim Savaşı, Mısır için hem son hem bir başlangıç olmuştur. Savaştan önce müttefiki Sovyetler Birliği'nden büyük ölçüde destek alan Mısır, savaşın başlangıcındaki başarısını saymazsak yine sonuçsuzlukla karşı karşıya kalmıştır. Mısır, İsrail sorununun çözümü için hem diplomatik hem de askeri olarak bütün seçeneklerini kullanmış olmasına rağmen bir çözüm üretmekte başarılı olamamıştır. Bu durum, Mısır için bir dip noktası iken, 1967'den beri süre gelen travmanın son noktası olan 1973 Savaşı, Mısır'a ABD'nin İsrail konusunda arabuluculuk yapması imkanını vermiştir. Bu gelişme, Mısır'ın süper güçlerle kurduğu ilişki tarihinde yeni bir sayfanın başlangıcı olmuştur.

Misır'ın Sovyetler Birliği’nden kopuşunda lider değişikliği faktörünün de etkisi vardır. Enver Sedat, birçok konuda Nasır'dan farklı düşüncelere sahip bir isim olmuştur. Nasır'dan daha az ideolojik bir bakış açışına sahip olan Sedat, liberal ekonomiye olumlu yaklaşmıştır. Komünizme bakışı ise

\footnotetext{
81 Blanga, "Nasser's Dilemma," 322.

82 A.g.e., 319.
} 
İslam'la komünizmin bağdaşmayacağ1 gerekçesiyle olumsuz olmuştur. ${ }^{83}$ Nasır'la arasındaki bir diğer önemli fark ise Enver Sedat'tın Nasır'ın sahip olduğu lider karizmasına ve Arap halklarının teveccühüne sahip olmamasıdır. Bu durum, Sovyetler Birliği ile oturduğu pazarlık masasında onun elini zayıflatmış; bu sebeple, Mısır'ın savunması için önem arz eden teçhizatların temini konusunda Sedat zorluklarla karşılaşmıştır. 1970'ler boyunca, Mısır'ın, Sovyetler Birliği'nden talep ettikleri karşısında ödeyeceği "bedelin" ne olacağ tartışmaları devam etmiştir. ${ }^{84}$

Enver Sedat'ın Sovyetler Birliği ittifakından ayrılma kararında etkili olan bir diğer neden olan meşruluk krizinin altında yatan iki önemli durum vardır. Bunlardan birincisi, Mısır'ın 1967 yılından beri deneyimlediği ekonomik kötüleşmenin devam etmesi olmuştur. Hem savaşın kendisinin yarattığı yıkım hem de "İsrail'le her an savaş başlayabilir" atmosferi, Mısır ekonomisini zora sokmuştur. Sürekli çatışma hali piyasaları öngörülemez ve istikrarsiz hale getirirken Misir'in liberal ekonomik politikalardan uzak duruşu yatırımcı için güvensizlik yaratmıştır. Sedat, bu problemlerin Sovyetleri Birliği'yle kurulmuş olan yakın ilişkiden kaynaklandığına inanmıştır. ${ }^{85}$ Ayrıca Sovyetler Birliği' nin, Mısır'ınborçlarınıyapılandırmaya yanaşmıyor oluşu, ekonomik darboğazı derinleştirirken halkın durumunu daha da kötüleştirmiştir. ${ }^{86}$ Ekonomik yardımların yapılması ve küçük devletin müttefiki tarafından desteklenmesi ittifak ilişkisinden beklenen faydalarken Sovyetler Birliği aksi yönde adımlar atmıştır. Bu durum, Sovyetler Birliği'nin itibar kaybetmesine yol açmıştır.

Meşruluk krizinin ikinci dinamiği, Mısır ve Sovyetler Birliği arasındaki yıpranmış ittifak ilişkisinden kaynaklanmıştır. 1950'li yıllardaki geri kalmışlık için Britanya ve ABD'nin suçlamasına benzer şekilde 1970'li y1llardaki problemler için de Sovyetler Birliği sorumlu görülmüştür. 1967 Savaşı'ndan sonra derinleşen Sovyet etkisine yönelik bir halk kızgınlığ meydana gelmiştir. ${ }^{87}$ Siyasi olarak, Sovyetler Birliği’ni eleştirmenin iç siyasette bir getirisi söz konusuydu. Bu sebeple "günah keçisi" olarak

\footnotetext{
83 Dawisha, Soviet Foreign Policy, 54.

${ }^{84}$ A.g.e., 56.

85 Ar1, Geçmişten Günümüze Ortadoğu, 193.

86 Dawisha, Soviet Foreign Policy, 77.

87 A.g.e., 55.
} 
Sovyetler Birliği eleştirilmiş ve halkın tepkisi iktidardan uzaklaştırılmaya çalışılmıştır. Ayrıca 1970'li yıllardaki ekonomik veya siyasal problemlerin ana kaynağı olan İsrail'le anlaşmazlığın çözümünde Sovyetler Birliği, diplomatik olarak etkisiz kalmış; İsrail üzerinde bir caydırıcıllı̆̆ olmamıştır. Misır'ın temel sorununun çözümünü sağlayabilecek tek gücün $\mathrm{ABD}$ olduğu gerçeği, Sovyetler Birliği ittifakının Mısır'ın çıkarları açısından yararlılığını sorgulatmıştır.

\section{3. İran: 1979 İslam Devrimi}

İran, yüzyıllardır büyük güçler arasındaki mücadelenin önemli sahnelerinden birisi olmuştur. 19. yüzyılda Britanya ve Rusya, İran'da etkin olabilmek için mücadele etmişken, İkinci Dünya Savaşı'ndan sonra sahnede ABD ve Sovyetler Birliği arasındaki mücadele yer almıştır. ${ }^{88}$ İran Şahı Muhammed Rıza, Batı'yla ilişkileri önemseyen ve ülkeyi laik standartlara kavuşturmak için çeşitli reformlar gerçekleştiren bir lider olmuştur. İran, Sovyetler Birliği'nin çevrelenmesi ve etki alanının sınırlandırılması amacına hizmet eden Bağdat Paktı'na üye olarak, ABD için Ortadoğu'daki önemli müttefiklerden birisi olmuştur. Öte yandan İran halkında geçmiş işgal tecrübelerinden beslenen bir yabancı düşmanlığ vard1. ${ }^{89}$ İç huzursuzluklar ve aşırı boyuttaki yabancı etkisinin yarattığ kızgınlık, dini nizamla ters düşen girişimler, Muhammed Rıza yönetimi ve halk arasında tansiyonun giderek yükselmesine neden olmuş; olayların zirve yaptığ 1979 yılında Şah devrilerek devrim gerçekleştirilmiştir. Devrimden sonra kurulan İran İslam Cumhuriyeti İran'ın, ABD'nin sadık müttefiki rolünü terk ederek yeni rejimin söyleminde ABD'yi “Büyük Şeytan" olarak konumlandırmıştır.

Soğuk Savaş dönemi boyunca, çok sayıda ABD askeri, İran'da görevlendirilmiş; Machain ve Morgan “ABD askerlerinin sınır ötesi görevlendirilmelerinin, Amerikan dış politikasının çıkarlarını ve belirli bir bölgeye olan adanmışlığını simgelediğini’"90 belirtmiştir. Grafik 7'de

88 Bruce R. Kuniholm, The Origins of The Cold War in The Near East: Great Power Conflict and Diplomacy in Iran, Turkey and Greece (New Jersey: Princeton University Press, 1980), 130.

89 Cleveland, Modern Ortadoğu Tarihi, 322.

90 Machain ve Morgan, “The Effect of US Troop," 104. 
Soğuk Savaş'ın başından beri İran' da askeri varlığını sürdüren ABD'nin, 1979'dan sonra İran'dan çekildiğini net olarak görmekteyiz. Bu durum, İran ve ABD arasındaki ittifakın sona erdiğinin bir göstergesidir.

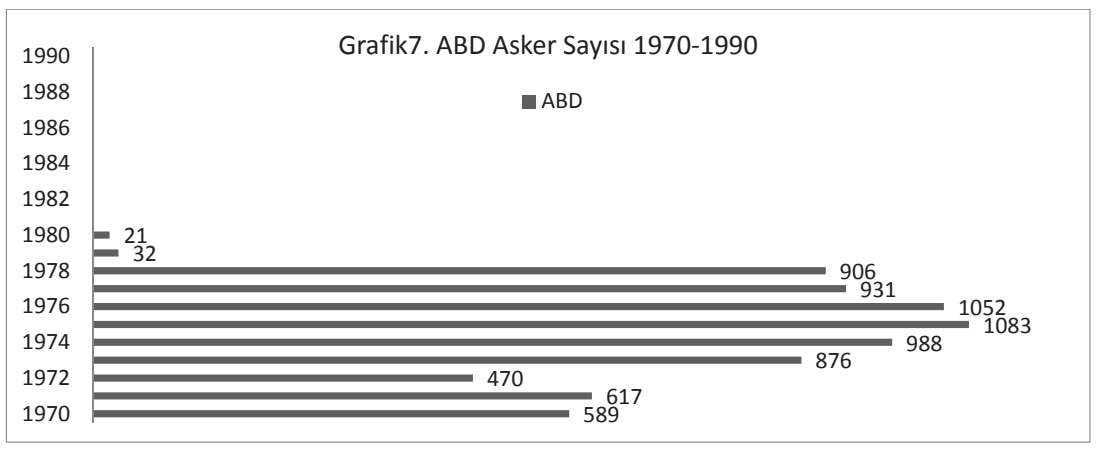

ABD'nin 1972 yılından itibaren yaptığı yardımlarda bir düşüş söz konusu olmakla birlikte 1979'dan itibaren hiç yardım yapılmaması dikkat çekicidir. Ayrıca ABD'nin yaptığı yardımların dışında, 1970'li yıllarda İran ve ABD arasında güçlü bir ticaret bağı vardı. İran ve $A B D$ arasında 8 nükleer santralin yapımını da içeren 15 milyar dolarlık bir anlaşma yapılmıştır. 1975 yılında Amerikalı yetkililer, ABD ve İran arasında askeriye ve petrol dışı ticaretin gelecek altı yıl içinde 23 milyar dolara ulaşacağ tahmininde bulunmuştur. ${ }^{91} 1979$ yılında yaşanan devrimle beraber bu beklentinin gerçekleşme ihtimali kalmamıştır.

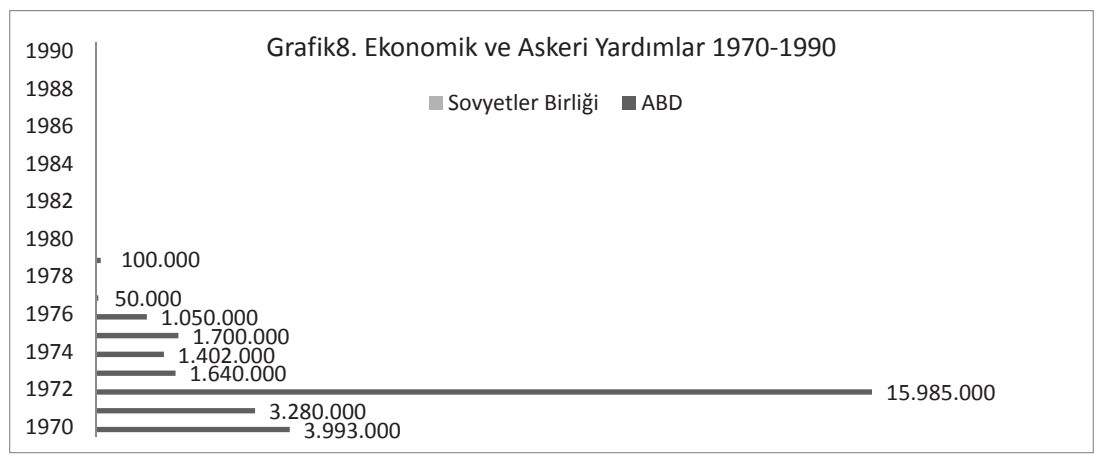

91 James A. Bill, The Eagle and The Lion: The Tragedy of American- Iranian Relations (New Haven: Yale University Press, 1988), 204. 
İttifakın önemli bileşenlerinden birisi üye devletlerin askeri güçlerini birleştirmesi ve eksiklerin tamamlanması olduğu için silahların ve askeri teçhizatların temininin müttefik devletten yapılması beklenir. ${ }^{92}$ İran 1979 yılına kadar silah alımlarının \%94,4'ünü Batı bloğu ülkelerinden yapmıştır. 1979 yılından sonra ise bu oran, \%0.33'e düşmüştür. Silah alışverişi verilerinin gösterdiği keskin düşüş, İran ve ABD arasındaki ittifakın sona erdiğini işaret etmektedir.

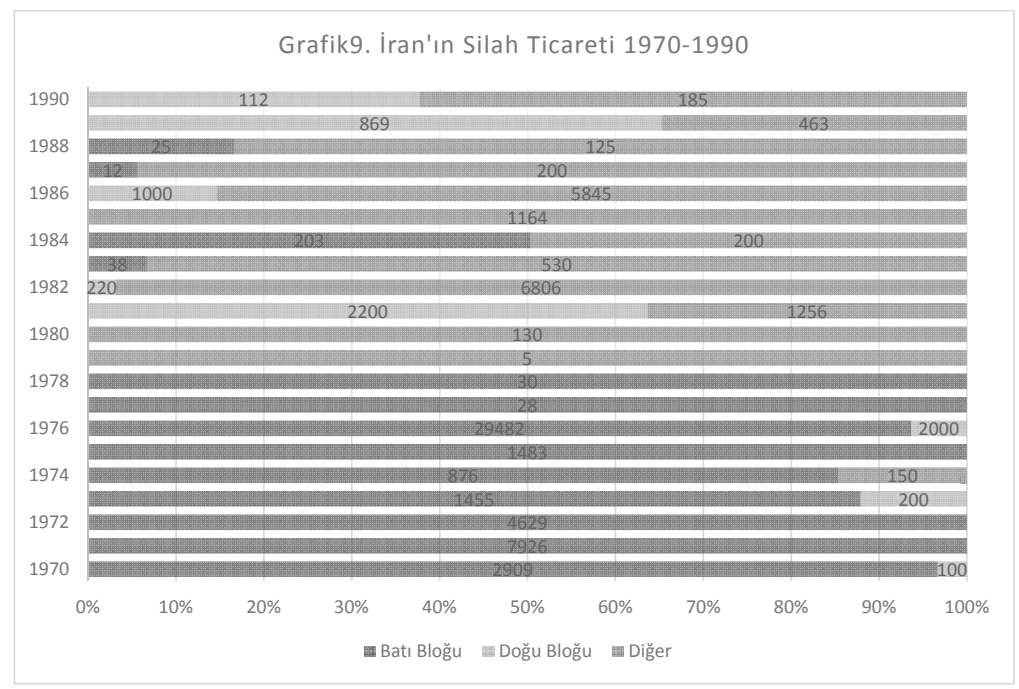

ABD'nin, İran'da olayların tırmanmasından sonra ülkeyi terk eden Muhammed Rıza Şah'1, tedavi için kabul etmesi, Ağustos 1953'teki darbeye Amerika'nın müdahalesinin acı anılarını hatırlatarak, tedirginlik içindeki taze devrim taraftarları üzerinde dejavu etkisi yaratmıştır. ${ }^{93} 400$ Üniversite öğrencisi, CIA'in 1953'ü tekrarlamayı planladıklarına ve Tahran'daki ABD Büyükelçiliği'ni üs olarak kullandıklarına inanarak büyükelçiliği ele geçirmiş; 66 diplomatik görevli, 444 gün süreyle rehin alınmıştır. ${ }^{94}$ Buna karşılık Başkan Carter, İran'dan petrol ihracatını durdurmuş ve diplomatik ilişkileri kesmiştir. ${ }^{95}$

92 Miglietta, American Alliance Policy, 2.

93 Abbas Amanat, Iran: A Modern History (New York: Yale University Press, 2017), 994.

94 Ervand Abrahamian, A History of Modern Iran (New York: Cambridge University Press, 2008), 168.

95 David Patrick Houghton, US Foreign Policy and the Iran Hostage Crisis (New York: Cambridge University Press, 2001), 2. 
Yukarıda açıklanan olaylar ve incelenen veriler, İran'ın ABD ittifakından ayrıldığını net olarak ortaya koymaktadır. Bu ayrılışın nedeni ise 1979 y1lında yaşanan rejim ve lider değişikliğidir. Devrimle birlikte İran'da iktidarı eline alan Şii dini nizamı devletin sistematiğini yeniden inşa etmiştir. Batılı değerlere hayranlık duyan ve dini çevrelerin etkisini ortadan kaldırarak laik bir sistem için çabalayan Muhammed Rıza'nın aksine gücü eline geçiren Şii din adamları, İslami şeriat üzerinde yükselen bir devlet hayalini kurmuştur. Şah yönetimine gösterdiği direnç ve keskin eleştirileri sebebiyle uzun yıllar sürgünde kalmış olan Ayetullah Ruhullah Humeyni, sürgündeyken bile vaazlarıyla İran halkı üzerinde etkili olmuştur. Humeyni'nin vaaz kasetleri halkta devrimci bir ruh uyandırmış ve onları ayaklanmaya davet etmiştir. ${ }^{96}$ Şah'ın ülkeyi terketmesinden sonra devrim lideri olarak ülkeye dönen Humeyni, velayet-i fakih ${ }^{97}$ adını verdiği yönetim yaklaşımını, İslam Cumhuriyeti'nin özü yapmayı başarmıştı. Anayasa değişikliğinde, İran'daki yasa ve kararnamelerin İslami kriterlere uygun olması koşulunun getirilmesiyle beraber, ulema devletin hakim idari yetkilisi konumuna yükselmiştir. İran siyasal, hukuki ve toplumsal olarak İslamlaşma yolunda adım atmıştır. ${ }^{98}$

İktidarın sahibi olanlar, devletin ayarlarını sıfırlayarak yeni bir kurgu inşa etmiş; devletin çıkarları, bölgesel ve küresel hedefleri yeniden şekillendirilmiştir. Humeyni’nin Muhammed Rıza yönetimini en çok eleştirdiği konulardan birisi, onun Amerika yanlısı politikaları olmuştur. ${ }^{99}$ Bu sebeple devrimin hedeflerinden birisi İran'ın ABD'ye olan bağımlılı̆̆ını sona erdirmek ve bağımsız bir dış politika izlemesinin yolunu açmak olmuştur. ${ }^{100}$ Yeni rejim için ABD bir müttefik alternatifi değildi ve yeni

96 Paul M. Shapera, Iran's Religious Leaders (New York: The Rosen Publishing Group, 2010), 30-2.

97 Şii inancına göre, hakimiyet İmam'ın hakkı olduğu için onun yokluğunda kurulmuş olan tüm hükümetler gayri meşru sayılır. Velayet-i fakih anlayışında ise İmamın temsilcileri olarak fakihlerin İmam gelene kadar halk1 idare etme yetkileri vard1. Ayrıntılı bilgi için bakınız. Ruhullah Humeyni, Velayet-i Fakih (Tahran: İmam Humeyni'nin Eserlerini Tanzim ve Yayınlama Müessesi-Uluslararası İlişkiler Bürosu, tarih yok); Serkan Taflıoğlu, "İran İslam Cumhuriyeti'nde Egemenlik ve Meşrutiyet Kaynağ1 "Velayet-i Fakih"," Ankara Üniversitesi SBF Dergisi 68, no. 3 (2013): 95112.

98 Cleveland, Modern Ortadoğu Tarihi, 477.

99 Shapera, Iran's Religious Leaders, 30.

100 Cleveland, Modern Ortadoğu Tarihi, 482. 
rejimin söyleminde ABD'nin yeri “Büyük Şeytan” olarak revize edilmiştir. Diğer örnek olaylardan farklı olarak, ABD'den uzaklaşan İran, Sovyetler Birliği ile yakınlaşma yoluna gitmemiştir. İran'ın yeni devlet vizyonunda, ABD "Büyük Şeytan” iken Sovyetler Birliği "Küçük Şeytan” olmuştur.

\section{Sonuç}

Çalışmada incelenen üç devlet -Irak, Mısır, İran- Soğuk Savaş döneminde süper güçlerle kurdukları ittifaklarında kopuş yaşamışlardır. Irak, Mısır ve İran'daki örnek olaylar, devletin birim düzeyindeki faktörlerinin, ittifak ayrılışı üzerindeki etkisini ortaya koymaktadır. Söz konusu ayrılışlar, rejim ve lider değişimi, travmatik deneyimler veya meşruluk krizi gibi devlet içi gelişmelerin, devletin tercihlerini ve yönelimlerini, iktidarın değer yargılarını ve ittifaka bakışını etkilediğini göstermektedir. İktidar erkini elinde bulunduranların, devletin çıkarlarını, ideolojisini veya yönelimlerini belirliyor oluşu, bu unsurların tek ve değişmez olmadığının kanıtıdır. Çıkarların sabit olmaması, bu çıkarların devlet içi unsurlardaki değişimlerden etkilenerek yeniden şekillendirilebileceği ve yorumlanabileceği anlamına gelmektedir. Devletin mevcut değerleriyle kurduğu ittifak ilişkisi, bu değerlerin değişmesiyle erozyona uğramaya açıktır. Rejim, lider değişikliği, travmatik bir olay ya da meşruluk krizi gibi nedenlerin sonucunda devlet, ittifak ilişkisini sona erdirebilir.

Irak'ın yaşadığ 1 askeri darbe ve İran'daki devrim, ülkelerindeki devlet yapısını baştan aşağıya değiştirerek "yeni oyun kurallarıyla" yeni bir düzen inşa etmiştir. Önceki iktidarın dayandığ 1 sosyal dengeleri alt üst ederek yeni bir toplumsal yapıyı ön plana çıkarmışlardır. Devletin çıkarlarının sübjektif doğası, yeni rejimin ve yeni liderin stratejik düşünce yapısı ve inançlarıyla, çıkarları yeniden şekillendirmesine olanak tanımıştır. ${ }^{101}$ Her iki devlette de yeni liderler, seleflerinden farklı dünya görüşlerine sahip oldukları için ülkeleri için biçtikleri roller de seleflerininkinden farklı olmuştur. Ayrıca devrik liderlerinin Batı düşkünlüğüne karşı tepki göstermişler ve iktidar olduklarında bu durumu ortadan kaldırmak için çaba harcamışlardır. Batı ile olan ittifaklarını sonlandırmaları, bu çabalarına bir örnektir. Mısır örneği ise birçok nedenin etkisi altında gerçekleşmesi ve ayrılışın bir süreç içinde

101 Richard Ned Lebbow, "Small States and Big Alliances," American Political Science Review 91, no. 3 (Eylül 1997): 706. 
yaşanması sebebiyle özel bir niteliğe sahiptir. Misır ve Sovyetler Birliği arasındaki ittifakın sorgulanmaya başlanması, 1967 Savaşı'na kadar geri gitmektedir. Savaşın ağır yenilgisi, Sovyetler Birliği'nin askeri ve ekonomik desteğine rağmen, Mısır'ın yetersizliğini aleni olarak ortaya çıkarmıştır. İsrail karşısındaki yenilginin travmatik şiddeti, Nasır'ın üstlendiği Arap liderliği rolünün sosyal inşası sebebiyle daha da şiddetlenmiştir. Bu olayın yarattığı travma, Mısır'1 alternatif arayışına yönlendirdi. Nasır döneminde, bir takım bölgesel ve uluslararası faktörlerin etkisiyle bu konuda bir ilerleme sağlanamamış olsa da travmanın yarattığı bilinçlenmenin etkisi uzun yıllar devam etmiştir. Enver Sedat da iktidarı boyunca bu alternatif arayışı içinde olmuştur. Mısır'ın ihtiyaç duyduğu kapasite ve imkanlardan yoksun oluşundan kaynaklanan çaresizlik sebebiyle Sedat, Mısır için başka bir koruyucu arayışına yönelerek Sovyetler Birliği ile olan ittifakı sonlandırmıştır. Ayrıca Mısır'ın ittifaktan ayrılış kararına zemin hazırlayan meşruluk krizi unsurunun altını çizmekte fayda vardır. Sovyetler Birliği ve Mısır arasındaki ilişki, Mısır'ın güçlenmesini ya da zenginleşmesini sağlamamış olmasının yanı sıra halkın gözünde Mısır'ın egemenliğini ihlal eden bir ilişki olarak nitelendirilmiş̧ir. Bu sebeple, yıpranmış durumdaki Sovyetler Birliği ittifakını eleştirmenin iç siyasette karşıllı̆ı olmuş; ittifakın gözden düşmesi, ittifaktan ayrılışı kolaylaştırmıştır.

Bu çalışma, sadece devlet birimi düzeyindeki faktörlerin, ittifak ayrılışlarına etkisini ortaya koymayı amaçladığı için yukarda açıklanan devlet düzeyindeki gelişmelerin, devletin ittifak tercihlerini şekillendirmede ne derecede etkili oldukları çalışmanın kapsamı dışında tutulmuştur. Devletin iç nedenlerinin, ittifak ayrılışı konusundaki etki gücünü kıyaslayan analiz çalışmalarının yapılması, gelecek araştırmalar için bir seçenek oluşturabilir. Örneğin, rejim ya da lider değişikliğinin önemli araçlarından birisi olan darbenin, ne oranda ittifak ayrılışıyla sonuçlandığı, Ortadoğu ve dünya tarihindeki bol örnekler incelenerek araştırılabilir. Ayrıca benzer bir çalışma dünyanın diğer bölgeleri için yapılarak süper güçle olan coğrafi yakınlığın, belirlenen nedenlerin ittifak ayrılışıyla sonuçlanmasını etkileyip etkilemediği veya süper güçlerin "arka bahçesindeki devletlerin" ittifaktan ayrılış kararı alma davranışları, daha uzak devletlerin ittifak davranışlarıyla kıyaslanarak değerlendirilebilir. Görüldüğü üzere, uluslararası ilişkiler disiplininin önemli konularından birisi olan ittifak ilişkileri, daha pek açıdan incelenmeye açıktır. 


\section{Kaynakça}

Abrahamian, Ervand. A History of Modern Iran. New York: Cambridge University Press, 2008.

Alexander, Jeffrey C. "Towards a Theory of Cultural Trauma." Cultural Trauma and Collective Identity içinde, Editörler: Jeffrey C. Alexander ve diğerleri, 1-31. Londra: University of California Press, 2004.

Amanat, Abbas. Iran: A Modern History. New York: Yale University Press, 2017.

Arı, Tayyar. Geçmişten Günümüze Ortadoğu Siyaset, Savaşve Diplomasi. Bursa: Dora Yayınları, 2014.

Armstrong, Adrienne. "The Political Consequence of Economic Dependence." The Journal of Conflict Resolution 25, no. 3 (Eylül 1981): 401-429.

Balc1, Ali. "A Three Level of Analysis of Turkey's Crisis with the U.S.-led Order." Insight Turkey 21, no. 4 (2019): 13-24.

Balc1, Ali. "Realizm." Uluslararası İlişkilere Giriş: Tarih, Teori, Kavram ve Konular içinde, Editörler: Şaban Kardaş ve Ali Balcı, 140-143. İstanbul: Küre Yayınları, 2015.

Barbieri, Katherine. "Economic Interdependence: A Path to Peace or a Source of Interstate Conflict?." Journal of Peace Research 33, no. 1 (Şubat 1996): 29-49.

Barnett Michael N. ve Jack S. Levy, "Domestic Source of Alliance and Alignments: The Case of Egypt, 1962-73." International Organization 45, no. 3, (Yaz 1991): 369-395.

Batatu, Hanna. The Old Social Classes and the Revolutionary Movements of Iraq: A Study of Iraq's Old Landed and Commercial Classes and of its Communists, Bathists, and Free Officers. New Jersey: Princeton University Press, 1978.

Bennett, Alexander J. "Arms Transfers as an Instrument of Soviet Policy in the Middle East." Middle East Journal 39, no. 4 (Illkbahar 1985): 745-774. 
Bennett, D. Scott. "Testing Alternative Models of Alliance Duration, 18161984." American Journal of Political Science 41, no. 3 (Haziran 1997): 846-878.

Berkowitz, Bruce D. "Realignment in International Treaty Organizations." International Studies Quarterly 27, no. 1 (Mart 1983): 77- 96.

Bill, James A. The Eagle and The Lion: The Tragedy of American- Iranian Relations. New Haven: Yale University Press, 1988.

Blanga, Yehuda U. "Nasser's Dilemma: Egypt's Relations with the United States and Israel, 1967-69." Middle Eastern Studies 51, no. 2 (Eylül 2014): 301-326.

Cleveland, William L. Modern Ortadoğu Tarihi. İstanbul: Agora Kitaplığı, 2008.

Crescenzi, Mark J.C., Jacob D. Kathman, Katja B. Kleinberg ve Reed M. Wood. "Reliability, Reputation, and Alliance Formation." International Studies Quarterly 56, no. 2 (Haziran 2012): 1-16.

David, Steven R. "Explaining Third World Alignment." World Politics 43, no. 2 (Ocak 1991): 233-256.

Dawisha, Karen. Soviet Foreign Policy Towards Egypt. Londra: Macmillan, 1979.

Donelly, Jack. "Realizm.” Uluslararası İlişkiler Teorileri içinde, Editörler: Scott Burchill ve diğerleri, 53-84. İstanbul: Küre Yayınları, 2013.

Downes, Alexander B. and Lindsey A. O'Rourke. "You Can't Always Get What You Want: Why Foreign-Imposed Regime Change Seldom Improves İnterstate Relations." International Security 41, no. 2 (2016): 43-89.

Farouk-Sluglett Marion ve Peter Sluglett. Iraq Since 1958: From Revolution to Dictatorship. New York: I.B.Tairus and Co Ltd., 2001.

Guan-Fu, Gu. "Soviet Aid to the Third World an Analysis of Its Strategy." Soviet Studies 35, no. 1 (Ocak 1983): 71-89.

Humeyni, Ruhullah. Velayet-i Fakih. Tahran: İmam Humeyni’nin Eserlerini Tanzim ve Yayınlama Müessesi-Uluslararası İlişkiler Bürosu, tarih yok.

Houghton, David Patrick. US Foreign Policy and the Iran Hostage Crisis. New York: Cambridge University Press, 2001. 
Kane, Tim. Global U.S. Troop Deployment 1950-2005, A Report of the Heritage Center for Data Analysis. Washington D.C.: The Heritage Foundation, 2006.

Keohane Robert O. ve Joseph S. Nye, "Power and Interdependence," Survival: Global Politics and Strategy 15, no. 4 (1973): 158-165.

Kimball, Anessa L. "Political Survival, Policy Distribution, and Alliance Formation." Journal of Peace Research 47, no. 4 (2010): 407-419.

Kuniholm, Bruce R. The Origins of The Cold War in The Near East: Great Power Conflict and Diplomacy in Iran, Turkey and Greece. New Jersey: Princeton University Press, 1980.

Lebbow, Richard Ned. "Small States and Big Alliances." American Political Science Review 91, no. 3 (Eylül 1997): 705-709.

Leeds, Brett, Jeffrey Ritter, Sara Mitchell ve Andrew Long. “Alliance Treaty Obligations and Provisions, 1815-1944." International Interactions: Empirical and Theoretical Research in International Research 28, no. 3 (Temmuz 2002): 237-260.

Levy, Jack S. "Domestic Politics and War." The Journal of Interdisciplinary History. 18, no. 4, (Bahar 1988): 653-673.

Machain, Carla Martinez ve T. Clifton Morgan. "The Effect of US Troop Deployment on Host States' Foreign Policy." Armed Force and Society 39, no. 1 (2013): 102-123.

Mangold, Peter. Superpower Intervention in the Middle East. New York: Routledge, 2013.

Marr, Phebe. The Modern History of Iraq. Colorado: Westview Press, 2012.

Miglietta, John P. American Alliance Policy in the Middle East, 19451992:Iran, Israel, and Saudi Arabia. Maryland: Lexington Books, 2002.

Morgenthau, Hans J. "A Political Theory of Foreign Aid." The American Political Science Review 56, no. 2 (Haziran 1962): 301-309.

Morgenthau, Hans J. Politics Among Nations: The Struggle for Power and Peace. Beijing: Pekin University Press, 1997. 
Morrow, James D. "Alliance and Asymmetry: An Alternative to the Capability Aggregation Model of Alliances." American Journal of Political Science 35, no. 4 (Kasım 1991): 904-933.

Neil, Arthur G. National Trauma and Collective Memory: Major Events in the American Centruy. New York: M. E. Sharpe Inc, 1998.

Pilster, Ulrich, Tobias Böhmelt, and Atsushi Tago. "Political Leadership Changes And The Withdrawal From Military Coalition Operations, 1946-2001." International Studies Perspectives 16, no. 4 (2015): 463 483.

Polat, Furkan. "Ortadoğu'daki Yapısal Değişimin Devletlerin İttifak Politikaların Etkisi: Suriye Örneği.” Türkiye Ortadoğu Çalışmaları Dergisi 4, no. 1 (2017): 74-102.

Renshon, Jonathan. "Stability And Change in Belief Systems: The Operational Code of George W. Bush." Journal of Conflict Resolution 52, no. 6 (2008): 820-849.

Rose, Gideon. "Neoclassical Realizm and Theories of Foreign Policy." World Politics 51, no. 1 (Kasim 1998): 144-172.

Shapera, Paul M. Iran's Religious Leaders. New York: The Rosen Publishing Group, 2010.

Sharp, Jeremy M. "Egypt: Background and US Relations." CRS Report. Washington: Congressional Research Service, 2019.

Sislin, John. "Arms as Influence: The Determinants of Successful Influence." The Journal of Conflict Resolution 38, no. 4 (Aralık 1994): 665-689.

Siverson, Randolph ve Harvey Starr. "Regime Change and the Restructuring of Alliances." American Journal of Political Science 38, no. 1 (Şubat 1994): 145-161.

Siverson Randolph M. ve Juliann Emmons, "Democratic Political System and Alliance Choices in the Twenth Century." Journal of Conflict Resolution 35, no. 2, (Haziran 1991): 285-306.

Smolansky, Oles M. ve Bettie M. Smolansky. The USSR and Iraq: The Soviet Quest for Influence. Durham ve Londra: Duke University Press, 1991.

Snyder, Glenn H. Alliance Politics. Ithaca: Cornell University Press, 2007. 
Sperling, James. "Neo-classical Realism and Alliance Politics." Theorising NATO: New Perspectives on the Atlantic Alliance içinde, Editörler: Mark Webber ve Adrian Hyde-Price, 1-92. New York: Routledge, 2016.

Taflıoğlu, Serkan. "İran İslam Cumhuriyeti'nde Egemenlik ve Meşrutiyet Kaynağ1 "Velayet-i Fakih"." Ankara Üniversitesi SBF Dergisi 68, no. 3 (2013): 95-112.

USAID Data Service. US Overseas Loans and Grants [Greenbook]. Washington D.C., 2019.

Walt, Stephen M. "Why Alliances Endure or Collapse." Survival: Global Politics and Strategy 39, no. 1 (1997): 156-179.

Witztum Eliezer ve Ruth Malkinson. "Death of a Leader: The Social Construction of Bereavement." When Community Weeps: Case Studies in Group Survivorship içinde, Editörler: Ellen S. Zinner ve Mary Beth Williams, 119-149. Washington, DC: Taylor \& Francis, 1998.

Zakaria, Fareed. "Realism and Domestic Politics." International Security 17, no. 1 (Yaz 1992): 177-198.

\section{İnternet Kaynakları}

Baghdad, Iraq Population 1950-2020, Son Erişim: 7 Mart 2020, https:// www.macrotrends.net/cities/21529/baghdad/population.

Görgün, Hilal. "Enver Sedat," TDV İslam Ansiklopedisi. İstanbul: TDV İslam Araştırmaları Merkezi, 1995. Son Erişim:13 Aralık 2019 https:// islamansiklopedisi.org.tr/enver-sedat.

Hevesi, Dennis. "Gaafar al- Nimeiry, A Sudan Leader Shifting Politics, Dies at 79." The New York Times. 15 Aral1k 2019. https://www.nytimes. com/2009/06/12/world/africa/12nimeiry.html.

SIPRI, Arms Trade Database, 2019, Son Erişim: 7 Temmuz 2019, http:// armstrade.sipri.org/armstrade/page/trade_register.php. 